Review

\title{
Amelogenin-Derived Peptides in Bone Regeneration: A Systematic Review
}

\author{
Antonino Fiorino ${ }^{1,2} \oplus$, Alessandro Marturano ${ }^{2}$, Giacomo Placella ${ }^{3}$, Edoardo Staderini ${ }^{1}{ }^{\circledR}$, \\ Lorena Igual Domingo ${ }^{4}$, Giuliano G. Cerulli ${ }^{5}$, Roberto Tiribuzi ${ }^{5, *}$ and Paolo Blasi ${ }^{6}$ (D) \\ 1 Department of Dentistry, Catholic University of Sacred Heart, 00168 Rome, Italy; \\ fiorinodr.antonino@gmail.com (A.F.); edoardo.staderini@unicatt.it (E.S.) \\ 2 GBR Academy, 50122 Florence, Italy; alessandro.marturano@hotmail.it \\ 3 Department of Traumatology and Orthopedics, San Raffaele Hospital, 20132 Milan, Italy; \\ giacomo.placella@gmail.com \\ 4 Department of Neurosciences, Dentistry Section, University of Padova, 35121 Padova, Italy; \\ lorenaigualdomingo@gmail.com \\ 5 Biology and Regenerative Medicine Laboratory, Translational Research Institute for the Locomotor System \\ Nicola Cerulli-LPMRI, 52100 Arezzo, Italy; giulianocerulli@gmail.com \\ 6 Department of Pharmacy and Biotechnology, University of Bologna, 40127 Bologna, Italy; p.blasi@unibo.it \\ * Correspondence: r.tiribuzi@irtal.com; Tel.: +39-0755058485
}

Citation: Fiorino, A.; Marturano, A.; Placella, G.; Staderini, E.; Domingo, L.I.; Cerulli, G.G.; Tiribuzi, R.; Blasi, P. Amelogenin-Derived Peptides in Bone Regeneration: A Systematic Review. Int. J. Mol. Sci. 2021, 22, 9224 https://doi.org/10.3390/ ijms 22179224

Academic Editor: Yousef Abu-Amer

Received: 5 July 2021

Accepted: 11 August 2021

Published: 26 August 2021

Publisher's Note: MDPI stays neutral with regard to jurisdictional claims in published maps and institutional affiliations.

Copyright: (c) 2021 by the authors. Licensee MDPI, Basel, Switzerland. This article is an open access article distributed under the terms and conditions of the Creative Commons Attribution (CC BY) license (https:/ / creativecommons.org/licenses/by/ $4.0 /)$.
Abstract: Amelogenins are enamel matrix proteins currently used to treat bone defects in periodontal surgery. Recent studies have highlighted the relevance of amelogenin-derived peptides, named LRAP, TRAP, SP, and C11, in bone tissue engineering. Interestingly, these peptides seem to maintain or even improve the biological activity of the full-length protein, which has received attention in the field of bone regeneration. In this article, the authors combined a systematic and a narrative review. The former is focused on the existing scientific evidence on LRAP, TRAP, SP, and C11's ability to induce the production of mineralized extracellular matrix, while the latter is concentrated on the structure and function of amelogenin and amelogenin-derived peptides. Overall, the collected data suggest that LRAP and SP are able to induce stromal stem cell differentiation towards osteoblastic phenotypes; specifically, SP seems to be more reliable in bone regenerative approaches due to its osteoinduction and the absence of immunogenicity. However, even if some evidence is convincing, the limited number of studies and the scarcity of in vivo studies force us to wait for further investigations before drawing a solid final statement on the real potential of amelogenin-derived peptides in bone tissue engineering.

Keywords: LRAP; TRAP; synthetic peptide; SP; amelogenin C11 peptide; regenerative medicine; bone diseases; biomineralization

\section{Introduction}

A wide range of pathological phenomena can be directly or indirectly responsible for skeletal tissue loss. Many of the generated defects, known as critical size defects (CSDs), do not heal spontaneously. The best option to treat CSDs is an autologous bone graft that possesses the three main features needed in bone regenerative medicine: osteogenic, osteoinductive, and osteoconductive properties. Unfortunately, autologous bone graft is rarely used due to a number of drawbacks, such as the requirement of a second surgical procedure with serious risks of infection at the donor site and the generation of significant pain.

Regenerative medicine and tissue engineering offer alternative strategies for the treatment of CSDs. In most of the approaches proposed, molecules capable of stimulating cell migration, recruitment, proliferation, and differentiation, as well as biomineralization, play a pivotal role in the formation of de novo bone tissue. Platelet-derived growth factors, insulin-like growth factors, transforming growth factors, and bone morphogenic proteins 
are examples of biomolecules investigated so far [1]. However, several efforts are still ongoing to individuate effective and safe bone morphogenic biomolecules. Among the biological macromolecules under investigation, amelogenins (AMG) represent an extremely interesting family of proteins with the above-mentioned characteristics for which the bone morphogenic properties are still matter of debate.

AMG are structural proteins secreted by the inner enamel epithelium during tooth development and represent about $90 \%$ of the enamel matrix proteins. Together with prolinerich proteins, such as ameloblastins, enamelins, and tuftelins, they direct the mineralization of enamel to form the highly organized rod matrix and the interrod crystals. AMG are highly conserved proteins, which are known to be essential in the formation of enamel [2].

AMG-based preparations were first proposed in the dermatological field for the treatment of burns and, only later, in dentistry. The first AMG formulation marketed for periodontal tissue regeneration procedures was Emdogain ${ }^{\circledR}$. The product contains a mixture of animal enamel matrix derivatives embedded in an alginate propylene glycol hydrogel. After 20 years, the use of Emdogain ${ }^{\circledR}$ in periodontal regeneration procedures has shown a statistically significant improvement in the recovery of the periodontal ligament, cement, and alveolar bone [3].

Although for over four decades, AMG was considered a specific enamel protein expressed in periodontal tissues, such as cementoblasts, periodontal ligament (PDL) cells, or Hertwig's epithelial root sheath (HERS) [4-7], its expression has also been reported, at a lower level, in non-dental cell types, such as stem cells, bone cells, brain, and other soft tissue [8-10]. Of interest are some observations suggesting that specific AMG splicing products may function as epithelial-mesenchymal or mesenchymal-mesenchymal signaling molecules [11-14]. In the late 1960s and early 1970s, two articles showed the osteoinductive potential of decalcified enamel and dentin extracts in ectopic sites $[15,16]$. This phenomenon was attributed to the presence of peptides with chondro-/osteoinduction properties derived from AMG gene splicing [17]. AMG-derived peptides are formed by alternative splicing or proteolytic cleavage of the $\sim 20 \mathrm{kDa}$ full-length protein $[18,19]$.

In this review, we discuss the structural and functional properties and the possible use in bone regeneration of natural and synthetic AMG-derived peptides. The article includes: a systematic review on the use of AMG-derived peptides in bone regeneration and a narrative review on the structure and function of AMG and AMG-derived peptides. The systematic review, which is focused on leucine-rich AMG peptide (LRAP), tyrosinerich AMG peptide (TRAP), synthetic peptide (SP), and AMGC peptide (AMG-CP or C11), attempts to answer the following questions: Do AMG peptides have osteoinductive capabilities? Which performs the best? Could their use in bone regenerative medicine/tissue engineering procedures be advantageous? The narrative part attempts to answer the following questions: What are AMG and what are their structures? What are the coding genes? Which cells synthesize AMG? What function do they have? Are they really useful in the regenerative field and on which tissues?

\section{Methods}

\subsection{Search Strategy and Literature Screening}

For the systematic review, two online databases (MEDLINE and Cochrane Library) were consulted for the publication period from 1980 to 20th January 2020 and the following search terms were used: "Amelogenin Peptide" OR "Leucine-rich amelogenin peptide" OR "Tyrosin rich amelogenin peptide" OR "LRAP" OR "TRAP" OR "Amelogenin Synthetic Peptide" OR "Amelogenin C Peptide" OR "Amelogenin Splice Product" OR "Amelogenins" AND “Osteoblast" OR "Bone" OR "Mineralized Tissue" OR "Mineral Nodule" OR "Tissue Regeneration" OR "Regenerative Medicine" OR "Tissue Engineering" ( $\mathrm{mp}$ = title, original title, abstract, name of substance, mesh subject heading). This systematic review was performed with PRISMA (Preferred Reporting Items For Systematic Reviews and MetaAnalyses) statement. 
For the narrative review, online databases and the publication period remained unchanged, while the search term combinations were: "Amelogenins" OR "Amelogenin Peptide" OR "Enamel Matrix Proteins" OR "Amelogenin Splice Product" OR "Leucine-rich amelogenin peptide" OR "Tyrosin rich amelogenin peptide" OR "LRAP" OR "TRAP" OR "Amelogenin C Peptide" ( $\mathrm{mp}$ = title, original title, abstract, name of substance, mesh subject heading).

\subsection{Exclusion Criteria}

Only studies involving bone formation evaluations in vitro and/or in vivo using amelogenin peptides were considered. The following exclusion criteria were applied:

- Articles not written in English;

- Letters;

- Duplicate publications (the article with the most recent data was preferred);

- Dental development;

- Guided tissue regeneration approach;

- Lacking mineral deposition or histomorphometric analysis;

- Bone formation not investigated.

\subsection{Study Selection and Data Extraction}

The selection procedures were conducted independently by three authors (AF, AM, and RT), and disagreements were resolved by full text analysis and a discussion session. The selection by titles and abstracts included articles that reported unclear or incomplete data in the full text analysis to minimize the possibility of excluding relevant articles. Selected publications, including already published reviews [11,20-23], were screened, and the bibliographies of all selected articles were checked so that other potentially relevant studies were also included in the analysis.

A specific dataset was created which included the following information: author, year of publication, type of study, objectives, type of cells used, type of peptide and concentration, culture medium, timing, presence of a control group and characteristics, outcomes, methods of analysis, and results. In case of incomplete or unclear information, the article's corresponding author was contacted. The articles were classified and described on the basis of the AMG peptides used.

\section{Results and Discussion}

\subsection{Systematic Review}

Electronic research identified 6171 studies, while a further 12 were collected by a manual search and references from selected articles and reviews. The selection sequence consisted of the evaluation of the title (2873 articles), of the abstract (774 articles), and subsequently of the complete text (24 articles) (Figure 1). Of the latter, 10 [24-33] were excluded due to the descriptive analysis (Table 1 ), while 14 studies met the inclusion criteria (Table 2). In the 14 studies selected [8,34-46], it was not possible to perform a quantitative analysis due to major differences in terms of the cell model, peptide concentrations, time points, and methodologies employed (Table 2). Among the included papers, there were no clinical trials, 13 were in vitro [8,34-39,41-46], and 1 was in vivo [40]. Only one article tested TRAP [38], five LRAP [8,34-37], six SP [39-44], and two the C11 peptide [45,46]. 


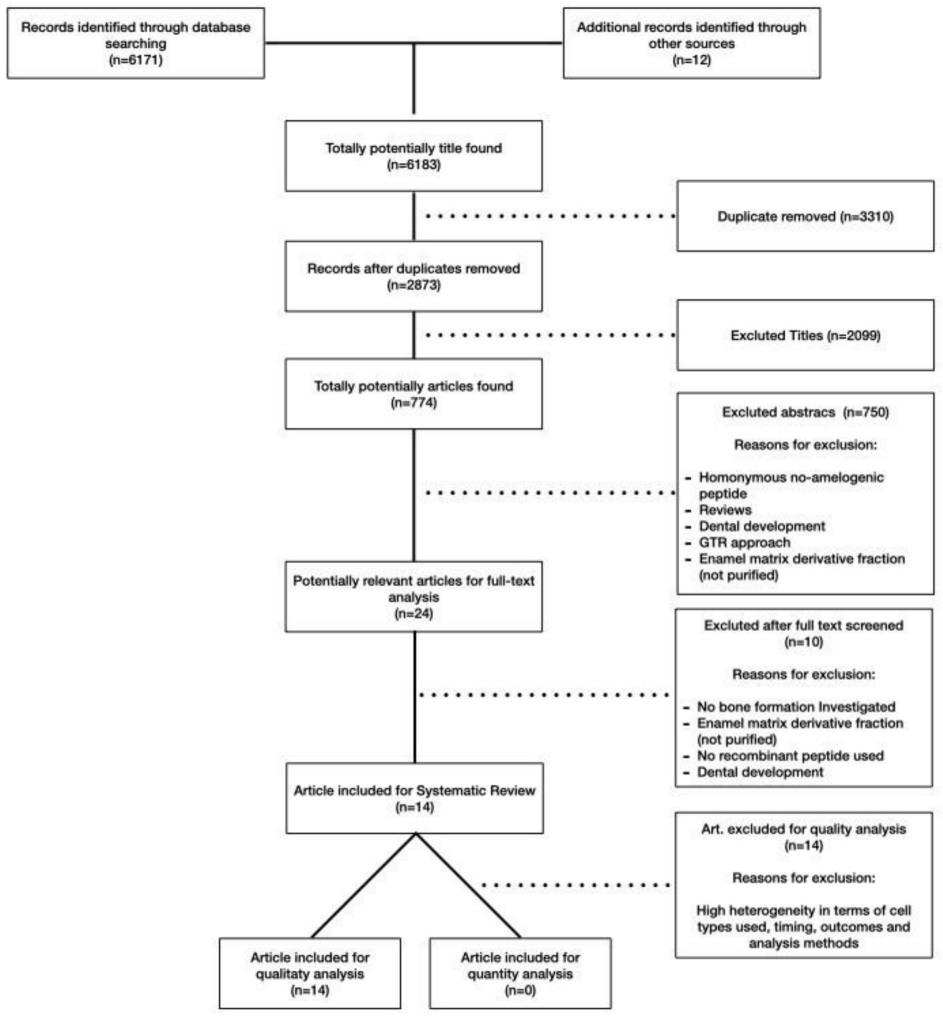

Figure 1. PRISMA flow chart and search strategy.

Table 1. Articles excluded from the systematic review. The table reports the main reason for the exclusion.

\begin{tabular}{|c|c|c|c|}
\hline First Author & Peptide & Main Exclusion Criteria & Ref. \\
\hline Boabaid et al. (2004) & LRAP & $\begin{array}{l}\text { Osteoblast differentiation not } \\
\text { investigated }\end{array}$ & [24] \\
\hline Le Norcy et al. (2011) & LRAP & Bone formation not investigated & [25] \\
\hline Hatakeyama et al. (2006) & LRAP & Bone formation not investigated & [26] \\
\hline Wang et al. (2006) & LRAP & Bone formation not investigated & [27] \\
\hline Amin et al. (2012) & TRAP and LRAP & No recombinant peptides & [28] \\
\hline Amin et al. (2014) & TRAP & No recombinant peptides & [29] \\
\hline Amin et al. (2011) & Enamel matrix derivative peptides & Bone formation not investigated & {$[30]$} \\
\hline Kim et al. (2005) & Enamel matrix derivative peptides & No recombinant peptides & [31] \\
\hline Ando et al. (2018) & C11 & No recombinant peptides & [32] \\
\hline Kunimatsu et al. (2018) & $\mathrm{C} 11$ & $\begin{array}{l}\text { Osteoblast differentiation not } \\
\text { investigated }\end{array}$ & [33] \\
\hline
\end{tabular}

Fifty percent of the selected articles evaluated, simultaneously, the effect of the various peptides on osteoblastic differentiation, deposition of mineral crystals, and cell proliferation [35,37,39,41-43,46]. 
Table 2. Articles dealing with the effect of LRAP, TRAP, SP, and C11 on bone regeneration included in the systematic review.

\begin{tabular}{|c|c|c|c|c|c|c|}
\hline First Author (Year) & Peptide & Cell/Cell Line & Concentration & Time Point & Main Results & Ref. \\
\hline Warotayanont et al. (2008) & LRAP & RW4 and $\mathrm{AMEL}^{-/-}$ESCs & $10 \mathrm{ng} / \mathrm{mL}$ & 10 and $20 \mathrm{~d}$ & $\begin{array}{l}\text { The addition of exogenous LRAP significantly increases the } \\
\text { mineral deposition and the expression of BSP and Osx. }\end{array}$ & [34] \\
\hline Warotayanont et al. (2009) & LRAP & RW4 and MC3T-E1 & $10 \mathrm{ng} / \mathrm{mL}$ & 4, 6 hand $20 \mathrm{~d}$ & $\begin{array}{l}\text { LRAP increases the level of Wnt agonist(s) and induced an } \\
\text { up-regulation of Osx and BSP of EB cells. The Wnt antagonist } \\
\text { sFRP-1 blocks LRAP-mediated osteogenesis. }\end{array}$ & [8] \\
\hline $\begin{array}{l}\text { Wen et al. } \\
\text { (2011) }\end{array}$ & LRAP & ST2 and MC3T3 cells & $10 \mathrm{ng} / \mathrm{mL}$ & $14 \mathrm{~d}$ & $\begin{array}{l}\text { LRAP treatment elevates the Wnt10b expression level and } \\
\text { promotes osteogenesis of mesenchymal stem cells. }\end{array}$ & [35] \\
\hline Newcomb et al. (2016) & LRAP & ST2 & $\begin{array}{l}0.15 \mathrm{nM}, 0.25 \mathrm{nM} \text { and } \\
1.5 \mathrm{nM}\end{array}$ & $14 \mathrm{~d}$ & $\begin{array}{l}\text { Gene expression was similar between LRAP and BMP-2 } \\
\text { treatment. LRAP enhanced osteo-differentiation through the } \\
\text { activation of the canonical Wnt/ } \beta \text {-catenin signaling pathway. }\end{array}$ & [36] \\
\hline Matsuda et al. (2017) & LRAP & MC3T3-E1 and ATDC5 & $10 \mathrm{ng} / \mathrm{mL}$ & $7,14,28 \mathrm{~d}$ & $\begin{array}{l}\text { LRAP could promote "in vitro" osteo-chondrogenic } \\
\text { differentiation. LAMP-1 may be involved in the } \\
\text { differentiation and proliferation of these cells. }\end{array}$ & [37] \\
\hline Amin et al. (2016) & TRAP & HACs & $1,10,50$ and $100 \mu \mathrm{g} / \mathrm{mL}$ & $21 \mathrm{~d}$ & $\begin{array}{c}\text { TRAP suppresses hypertrophic mineralization and } \\
\text { concomitantly promotes chondrogenic differentiation of } \\
\text { HACs. }\end{array}$ & [38] \\
\hline Kawanaka et al. (2009) & SP & HPdLF & 1,10 and $100 \mathrm{ng} / \mathrm{mL}$ & $7 \mathrm{~d}$ & $\begin{array}{l}\text { The mRNA content of BMPR1A was increased in HPdL F } \\
\text { cultured with synthetic peptide. SP might convert HPdLF to } \\
\text { bone-forming cells. }\end{array}$ & [39] \\
\hline $\begin{array}{l}\text { Hida et al. } \\
\quad(2010)\end{array}$ & SP & In Vivo study (rats) & $\begin{array}{l}0.3,3,7.5,15 \text { and } \\
\quad 30 \mathrm{mg} / \mathrm{mL}\end{array}$ & $1,3,5,7,14 \mathrm{~d}$ & $\begin{array}{l}\text { The synthetic peptide combined with an extended-release } \\
\text { scaffold seems to produce hard tissues, such as cartilage and } \\
\text { bone. }\end{array}$ & [40] \\
\hline Yasui et al. (2012) & SP & RBMCs & $\begin{array}{l}20,100,500 \text { and } \\
1000 \mathrm{ng} / \mathrm{mL}\end{array}$ & $7,14 \mathrm{~d}$ & $\begin{array}{l}\text { SP facilitates cell proliferation and induces differentation into } \\
\text { osteoblast. }\end{array}$ & [41] \\
\hline Taguchi et al. (2012) & SP & HPdLF & $\begin{array}{l}5,20,100,200 \text { or } \\
500 \mathrm{ng} / \mathrm{mL}\end{array}$ & $28 \mathrm{~d}$ & $\begin{array}{l}\text { SP accelerated calcification, increases ALP activity and OCN } \\
\text { production. }\end{array}$ & [42] \\
\hline Kato et al. (2013) & SP & PDLSC & $100 \mathrm{ng} / \mathrm{mL}$ & $2,3,5,7,21 \mathrm{~d}$ & $\begin{array}{l}\text { SP enhances the formation of calcified nodules and } \\
\text { osteocalcin production. }\end{array}$ & [43] \\
\hline Katayama et al. (2014) & SP & MSCs & $\begin{array}{c}0.1,10,100 \\
\text { and } 1000 \mathrm{ng} / \mathrm{mL}\end{array}$ & 7 and $14 \mathrm{~d}$ & $\begin{array}{l}\text { SP promotes cell proliferation, osteoblast differentiation, and } \\
\text { mineralization in human MSCs. }\end{array}$ & [44] \\
\hline Awada et al. (2017) & C11 & MC3T3-E1 & 0,100, or $1000 \mathrm{ng} / \mathrm{mL}$ & $7,14,21 \mathrm{~d}$ & $\begin{array}{l}\text { Enhanced cell proliferation, but no difference with control } \\
\text { group in terms of osteogenic differentiation and expression of } \\
\text { ALP and BSP was observed. }\end{array}$ & [45] \\
\hline Kuminatsu et al. (2017) & C11 & HCEM & $0,10,100$ or $1000 \mathrm{ng} / \mathrm{mL}$ & $1,7,14,21 \mathrm{~d}$ & $\begin{array}{l}\text { Osteogenic differentiation was significantly enhanced by } \\
\text { treatment with rh128 and C11 peptide but not with rh163. }\end{array}$ & [46] \\
\hline
\end{tabular}




\subsection{Amelogenins}

\subsubsection{Proteins and Genes}

AMGs were described for the first time by Eastoe in 1965 [47], but the first amino acid sequence (bovine) was reported by Takagi et al. only in 1984 [48]. AMG is encoded in the $\mathrm{X}$ and $\mathrm{Y}$ chromosomes, both genes are expressed, and the transcript undergoes alternative splicing leading to different AMG isoforms. In humans, the AMG protein is mainly encoded (approximately $90 \%$ ) by the $X$ chromosome. Lau and coworkers identified the 7 exons AMG genes on sex chromosomes in humans, on the $X$ and $Y$ chromosomes by Southern blot analysis of human-rodent cell hybrid [49]. In the following years, amino acid sequences from several mammalian species were identified [50-52]. Nakahori et al. [53] reported two genomic sequences of AMG genes; one copy of the AMG genes was located on the distal short arm of the $X$ chromosome in the Xp22.1-Xp22.3 region (AMELX), while the second copy was near the centromere of the $\mathrm{Y}$ chromosome in the Yp11.2 region (AMELY). The AMELX is localized within the intron 1 of the ARHGAP6 gene, with an opposite orientation to the nested gene [54]. In humans, the homology between AMELX and AMELY genes is about $88.9 \%$, while between the two cDNA sequences, it is about $91 \%$.

Globally, $90 \%$ of all transcripts derive from the 7 exons X-linked gene. Translation starts from exon 2, with exon 4 being frequently skipped. More than 15 different mRNAs were described from AMELX gene.

The mature human AMG from the $X$ chromosome, skipping exon 4 , is a protein of $19.8 \mathrm{kDa}$ with 180 amino acid residues [55,56], while the $\mathrm{Y}$ chromosome produces a $21.6 \mathrm{kDa}$ protein with 190 amino acids (data from www.uniprot.org, accessed on 30 July 2021).

Differences between AMELX and AMELY are used in sex determination. AMELX intron 1 contains a 6 bp deletion relative to intron 1 of the $A M E L Y$. This can be detected by polymerase chain reaction (PCR) of intron $1[57,58]$. Starting from the consideration that human teeth have been considered as a prime choice in determining the identity of an individual, recently, several works have described the use of AMG genes in forensics. Dutta et al. showed that pulpal tissue along with degenerating odontoblastic processes yield a sufficient amount of DNA for gender determination with maximum accuracy by PCR [59]. They have also shown the reliability of the test even in teeth exposed to extreme environmental conditions or insults [60].

So far, five different AMG isoforms and numerous peptides have been described. Figure 2 reports the BLAST comparative analysis between Amelogenin X isoform 1 (Swiss prot: Q99217) and the other four isoforms (Amelogenin X isoform 2, Swiss prot: Q99217-2; Amelogenin X isoform 3, Swiss prot: Q99217-3; Amelogenin $Y$ isoform 1, Swiss prot: Q99218-1; Amelogenin Y isoform 2, Swiss prot: Q99218).

AMG are part of a heterogeneous family of proteins that undergo proteolytic degradation, resulting in enamel formation. According to the amino acid physico-chemical characteristics, the primary structure can be organized into three main domains, including the signal peptide at the N-terminal. The first domain, TRAP, is a highly conserved hydrophobic domain (aa 1-45) that includes the tyrosyl binding motif (aa 34-45) and the kallikrein 4 (KLK4) cleavage site between amino acids 45 and 46 . The second domain (aa 46-150), located in the central hydrophobic core, is characterized by the Xxx-Yyy-Pro repetitive motifs. This domain is not involved in cleaved peptide production since it is included between KLK4 and matrix metalloproteinase 20 (MMP-20) cleavage site. The C-terminal domain (aa 151-180) is the hydrophilic region of the protein containing three MMP-20 catalytic sites [2,61,62]. 


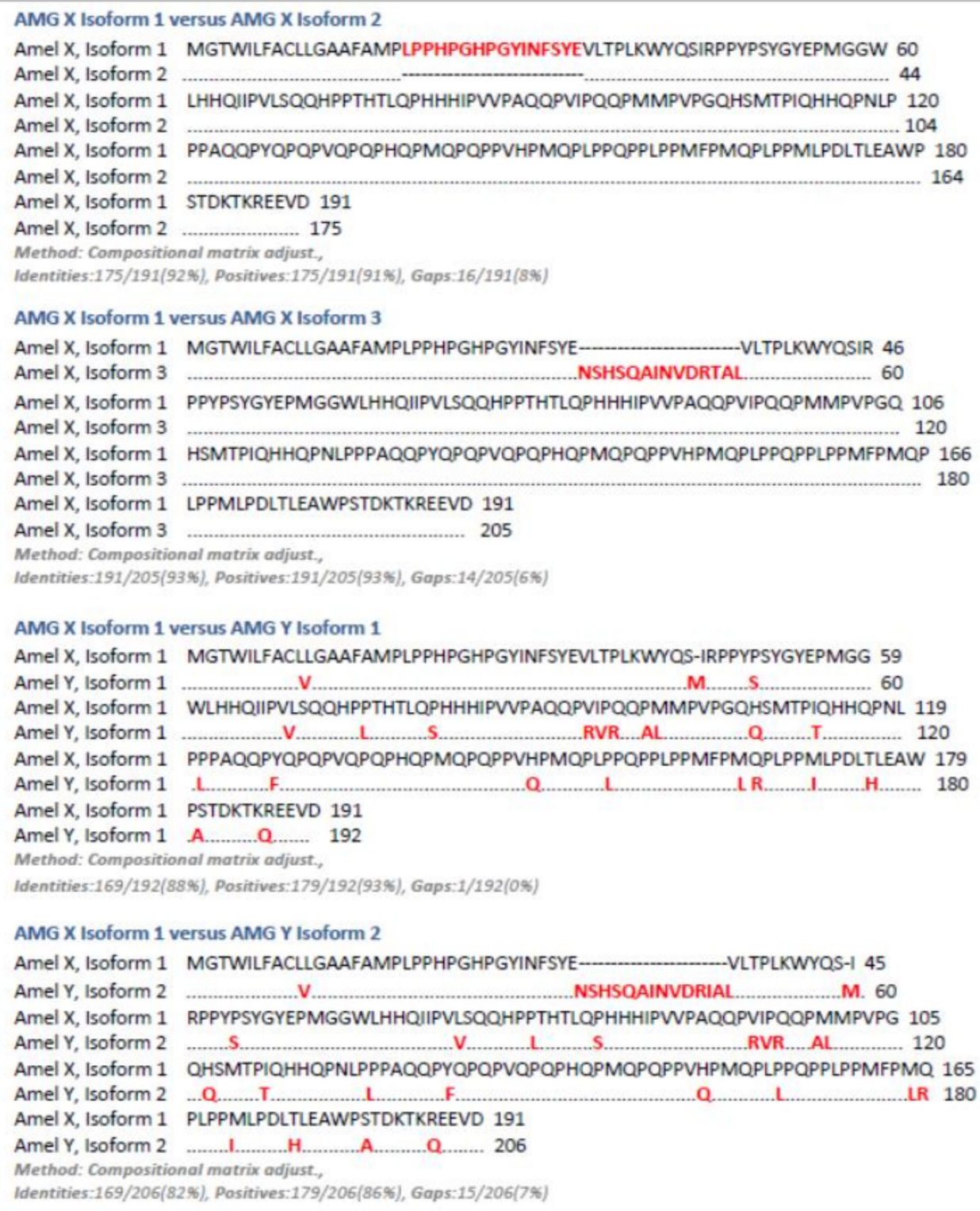

Figure 2. BLAST pairwise with dots for identities between Amelogenin $\mathrm{x}$ isoform 1 and the other four isoforms.

The primary structure of the N- and C-terminal ends are highly preserved among species, while small variations were reported in the middle domain, mainly deletions or insertions of Xxx-Yyy-Pro motif [63].

The secondary structures consist of a large fraction of $\beta$-sheets, turns, and random coils with minor $\alpha$-helix fractions $[64,65]$. The $\mathrm{N}$-terminal region seems to contain betastrand structures, and the mid-section is rich in polyproline II and $\beta$ turns, while the C-terminal region displays characteristics of a random coil conformation. $\mathrm{A} \mathrm{Ca}_{2}{ }^{+}$binding site, constituted by repetitive beta-turn segment and a "beta-spiral", is also present $[2,66]$.

To date, the AMG tertiary structure has not been well characterized, but its supramolecular assembly in nanospheres has been described [66]. AMG forms nanospheres by binding hydroxyapatite crystals with both the N-terminal and C-terminal domains. The central region forms the dense central area of the nanospheres. The function of the $\mathrm{C}$-terminal hydrophilic domain is critical in the early stage of enamel formation but, during the protein secretion into the extracellular space, it is influenced by the MMP-20 catalytic cleavage.

AMG showed a quaternary structure as a function of $\mathrm{pH}$ (monomers at $\mathrm{pH} 3$; oligomers at $\mathrm{pH}$ 5.5; nanospheres-self-assemblies of oligomers-at $\mathrm{pH} \geq 6.8)$ and concentration [67]. 
It has been suggested that the $\mathrm{N}$ - and C-terminal domains play important roles in controlling the interactions [68], size, polydispersity [69], and hierarchical structure [70] of the nanospheres, while the central hydrophobic core promotes oligomer-oligomer binding. The N-terminal region includes a tyrosyl motif that binds acetylglucosamine and keratins, which may alter nanosphere formation and $\mathrm{AMG}^{\prime}$ s biological role in enamel mineralization.

AMG undergoes sequential proteolysis by MMP-20 and KLK4 during enamel secretion and maturation, resulting in highly heterogeneous fragments in the enamel matrix, with a molecular weight ranging from $\sim 5$ to $\sim 25 \mathrm{kDa}$, depending on proteolytic degradation and alternative mRNA splicing [51].

\subsubsection{Biology and Translational Research}

Enamel matrix derivatives (EMD) have been used in periodontal disease therapy to induce the regeneration of lost periodontal tissue [71]. In dentistry, it is used for the surgical treatment of vertical bone defects that are formed around the teeth due to periodontitis. Based on the high degree of sequence homology between human and porcine enamel proteins, non-erupted developing pig premolars and molars have been employed to produce EMD. Emdogain ${ }^{\circledR}$ is a commercial preparation of enamel matrix proteins composed primarily of AMG. Because of the animal origin, a batch-to-batch variability and the production of anti-EMD antibodies in the host have been reported. Two systematic reviews $[3,72]$ have confirmed that EMD helps to restore the tissues destroyed by bacterial infection. However, the clinical trial heterogeneity imposes a certain caution in the analysis of the real treatment efficacy [72]. In addition, for a long time, the exact EMD composition was undisclosed. Now we know that the major EMD components are AMG and their fragments [73-76], with molecular weights ranging from 5 to $20 \mathrm{kDa}$ [77]. The remaining portion is constituted by ameloblastin, enamelin, tuftelin, enamelysin, and enamel matrix serum proteinase 1, now officially designated KLK4 [5,78-84].

AMG's biological effects are a function of the isoform/fragment employed, their concentrations, implantation site, and delivery modality. Its activity also depends, in vitro, on cell type and differentiation stage, and, in vivo, on the selected animal model [85]. For instance, in studies on vascular cells, periodontal ligament, and osteoblasts, AMG stimulates proliferation and differentiation [86], as well as transforming growth factor $\beta$ (TGF- $\beta$ ) [87] and vascular endothelial growth factor (VEGF) release [88]. The different EMD production methods and the batch-to-batch variability might be also responsible for the different biological activity sometimes observed [44].

Regarding EMD's regenerative potential assessed in clinical periodontology, where different tissues and cells were evaluated (guided tissue regeneration), readers may refer to the cited clinical reviews [5,72].

Focusing the discussion on bone tissue regeneration, EMD was tested on different osteoblast cell-lines such as MG63, MC3T3-E1, human osteoblast 2T9, and rat calvaria osteoblasts. Common denominators in treated cells were the increased proliferation, early differentiation, increased secretion of IL-6, type I collagen, osteoprotegerin (OPG), TGF- $\beta 1$, and the inhibition of osteoclastogenesis [78,86,89-94].

Interestingly, using precursor cells such as $\mathrm{C} 2 \mathrm{C} 12$, mesenchymal cell line, murine macrophage cell line RAW 264.7, porcine alveolar bone cells, and the stromal cell line ST2, EMD was found to stimulate osteogenic and/or chondrogenic lineages. It was reported that the osteopontin (OPN) and CBFA1/RUNX2 mRNA expression and the phosphorylation of SMAD1 may be mediated by a bone morphogenetic protein (BMP)-like peptides present in EMD [74,95-100].

Recently, Miron and coworkers demonstrated that Osteogain ${ }^{\circledR}$, another commercial EMD formulation, increases ST2 pre-osteoblast attachment and osteoblast differentiation in vitro [101]. However, these results conflict with previous studies of the group of Nishihara, which have shown that EMD induces osteoclastogenesis through RANKL expression in primary osteoblasts and RAW 264.7 cells $[102,103]$. 
Results from in vivo studies in large bone defects or CSD showed that EMD is not effective in the stimulation of new bone formation [104-106]. On the other hand, three studies have reported a significantly higher bone fraction volume of newly formed bone trabeculae in the EMD-treated group, seven days after injury [107-109]. However, it seems that the best results were reported in the presence of restraints and not in large bone defects or CSD showing some osteopromotion activity in the early healing phases. It is important to emphasize that the observational periods (maximum four weeks) are very short compared to the time required for complete bone repair, which is estimated to be close to 36 months [110].

These concerns agree with those reported by Cornelini et al. on the duration of the EMD activity [111]. In fact, Emdogain ${ }^{\circledR}$ is completely resorbed after four weeks and does not support either the stability of the blood clot or the space maintenance for sufficient time [112]. It is, therefore, possible to hypothesize that the short half-life and lack of dimensional stability negatively affect the release kinetics of the AMG with osteoinductive activity present in the EMD. Interestingly, Miron et al. have described that additional benefit may arise by using natural bone mineral particles pre-coated with EMD. This combination improves new bone formation after four and eight weeks post-implantation [113].

The identification of the EMD component(s) responsible for the osteoinductive activity will allow the use of synthetic peptides (standardized composition), leading to a deeper understanding of their actual effectiveness in bone tissue engineering [114]. With this aim, Iwata et al. have fractionated enamel matrix extract from porcine teeth and described an osteoinductive fraction (OFE) containing mainly proteins with a MW ranging from 20- to $23 \mathrm{kDa}$ [115]. This fraction has induced a mineralized nodule formation and an up-regulated osteocalcin (OCN), bone sialoprotein (BSP), and alkaline phosphatase (ALP) mRNA expression in ST2 cells without affecting their proliferation. The chromatographic separation of EMD allowed them to highlight fractions with different functions. In particular, the fractions 4-6 showed BMP-like activity, while the fractions 8-13 had TGF $\beta$-like activity [75]. Exposure of mouse osteoblast-like cells (ST2) to fraction 3 (extracted from porcine permanent molars) reduced ALP activity, whereas fraction 2 showed an opposite effect, inducing an increased ALP activity [19].

Another research frontier was opened using recombinant AMG that showed significantly higher osteoinductive effects than EMD alone. Hoang et al. showed that recombinant porcine AMG (rP172) promotes adhesion of MG63 cells [116], and recombinant murine AMG (rM179) incorporated into a biomimetic apatite layer induced a significant increase in gene expression level of type I collagen, ALP, and OCN, as well as an enhanced cell attachment and spreading in human embryonic palatal mesenchymal preosteoblasts (HEPM 1486) [117]. Commercially available primary human osteoblasts exposed to $\mathrm{rp}(\mathrm{H}) \mathrm{M} 180$, a recombinant murine histidine-tagged AMG, showed about a 2-fold increase of secreted OCN with respect to the negative controls [118]. Terada et al., using an AMG-coated TNS-modified titanium surface, showed an increased ALP activity, OCN production, calcium deposition, and osteogenesis-related gene expression in RBM cells. They observed differences in the expression levels of osteoblast-specific markers between AMG-coated and uncoated TNS-modified titanium implant surfaces: an upregulation of Runx2 and BMP, which are key transcription factors mediating osteoblast differentiation, and ALP and OPN levels in RBM cells grown on the coated surface that reflected its greater capacity for inducing osteogenic differentiation. These data suggest that AMG maintains the viability of adherent stromal cells and promotes their osteoblastic differentiation [119].

An interesting aspect is the interaction between AMG and other proteins and the signaling pathways involved. AMG has been shown to exhibit several characteristics of cell adhesion proteins but, since it does not contain an RGD or other specific adhesion sequences, the involved receptor may not be an integrin [116]. Putative full-length AMG (rM180) binding partners were identified in SaOS-2 osteoblastic cells. They include chaperone molecules (HSP70 family proteins), cytoskeletal proteins (actin, vimentin, tubulin), actin-binding proteins (gelsolin, tropomyosin), proton pump proteins (ATPase), sialic acid-binding Ig-like 
lectins (Siglec-10), stress-inducible endoplasmic reticulum chaperone proteins (glucoseregulated protein 78, Grp78), calreticulin (CRT)), mitochondrial membrane proteins (prohibitin), and nuclear proteins (nucleophosmin and hnRNP A2/B1) [120]. Some candidate receptors are: LAMP1 in murine dental follicle cells and OCCM-30 cells [121]; LAMP1 and CD63 in human osteoblast (hFOP_1.19), murine pre-osteoblast cells (MC3T3-E1) and mouse ameloblast-like LS8 cells [122]; and Grp78 in SaOS-2 [120] and undifferentiated Human Periodontal Ligament (HPDL) cell line [123].

Previous studies have also demonstrated that recombinant full-length AMG (rM180) can rapidly move into the cell, through LAMP1 or LAMP3 (CD63)-positive vesicles, and subsequently localize to the perinuclear region in ameloblast [122], osteoblast $[120,123]$, cementoblast, and dental follicle cells [121]. There is also evidence that enamel matrix proteins are internalized by primary human osteoblasts through clathrin-coated pits, indicating a receptor-mediated endocytosis [90].

In contrast to murine cementoblasts (OCCM-30) [85], human-derived cementoblasts treated with full-length AMG (rh174) showed an increased expression of tissue-nonspecific ALP, OCN, BSP, and mineralized nodule formation [124]. In fact, full-length AMG reduced OCCM-30 differentiation potential, featuring an increased osteopontine and a decreased osteocalcin mRNA levels. No change or a down-regulation of BSP, as well as a reduction in mineralized nodule formation, were reported $[24,125,126]$.

\subsection{LRAP}

The Leucine-Rich Amelogenin Peptide (LRAP) is a 59-residue natural splice-variant of AMG [127]. The spliced mRNA encodes a 79-residue peptide referred to as Pro-LRAP that undergoes the telopeptide proteolytic cleavage between residue 167 and 168 by MMP-20 leading to the mature LRAP. This peptide was isolated and purified from secretory enamel matrix by Fincham and coworkers in 1981 [128], but only later was it recognized as an osteogenesis-inducing factor [17]. The 59-residue peptide is composed of the first 33 and last 26 AMG residues and is a naturally occurring product of alternative splicing of the primary mRNA transcript, with the $\mathrm{N}$ - and C-terminal charged regions of the full-length protein.

The secondary structure is mainly constituted by random coils in the C-terminus and N-terminus of the protein [129-131], even though numerical simulations suggest the presence of partially helical regions at the C-terminus (aa 48-55) and the N-terminus (aa 12-17) [131].

Yamazaki and colleagues have investigated the role of protein phosphorylation on LRAP secondary structure in the presence of hydroxyapatite and amorphous calcium phosphate. They showed that LRAP(-P) mainly consist of random coil and PPII helix or $\beta$-sheet structure, while $\operatorname{LRAP}(+\mathrm{P})$ exhibits more $\beta$-sheet and $\alpha$-helix, with little random coil. With the addition of $\mathrm{Ca}^{2+}$, the random coil content increased in $\operatorname{LRAP}(-\mathrm{P})$, while $\operatorname{LRAP}(+\mathrm{P})$ exhibited a decrease in $\alpha$-helix components. Incubation of LRAP(-P) with hydroxyapatite or amorphous calcium phosphate resulted in comparable increases in $\beta$-sheet structure. Notably, $\operatorname{LRAP}(+\mathrm{P})$ secondary structure was more affected by amorphous calcium phosphate than by hydroxyapatite, mainly showing an increase in $\beta$-sheet structure [132].

LRAP seems flexible enough to have several possible tertiary conformations.

Concerning quaternary structure, LRAP is primarily a monomer over a wide range of concentrations, $\mathrm{pH}$ values, salt concentrations, and in the presence of calcium. However, Ma et al. showed a hierarchical LRAP self-assembling with the formation of nanospheres, nanorods, associated nanospheres (nano strings), gel-like precipitations, and amyloid-like structures. LRAP amyloid-like supramolecular structures are assemblies containing a consistent rigid $\beta$-sheet secondary structure (residues 12-27) that seems to be essential for amyloidogenic aggregation [133]. LRAP monomers are the dominant species in solutions at $\mathrm{pH}$ values higher than the isoelectric point, but the solutions also contain a relatively low concentration of oligomeric species $(0-16 \%)$. The differences in quaternary structures between LRAP and AMG may show which domains are important in the formation of 
supramolecular structures. Indeed, the missing central region is necessary for nanosphere formation since it promotes oligomer-oligomer binding.

Several studies have tried to elucidate the physiological role of LRAP in enamel formation. Its involvement in cell signaling $[8,24,34,35,134]$, in the regulation of the calcium phosphate mineralization kinetics, and the morphology of formed crystals has been reported $[25,132,135]$. LRAP shares many common properties with the full-length AMG in the regulation of mineral formation in vitro: it forms nanospheres $[25,136,137]$ and binds hydroxyapatite $[138,139]$. In vitro experiments using non-phosphorylated recombinant human LRAP and recombinant human AMG (rH174) showed that they have the same ability to bind calcium (i.e. 4 to 6 calcium ions per molecule), although the calcium affinity constant for the LRAP was greater than that observed for AMG [140].

\subsubsection{LRAP as a Cell Agonist}

Some AMG isoforms do not seem to have biological activity, while others activate intracellular signaling pathways in cementum-derived cells $[24,121,125]$ and have a great periodontal regeneration potential $[5,23,141]$.

LRAP has been shown to be the main factor within enamel matrix derivatives to promote osteogenesis. It was reported that human and mouse ameloblast cells (LS8), after a treatment with rh58 (recombinant human LRAP) and M59 (murine LRAP), showed an upregulation of AMG, a down-regulation of the Notch1 expression, and an increased synthesis of total nitrites $[140,142]$. Nitric oxide (NO) is a key molecule involved in the regulation of survival, proliferation, and differentiation in many cell types. Interestingly, an increased NO level has been shown to regulate cell differentiation [143,144]; in fact, it is considered a key negative cell cycle regulator, blocking cell proliferation, a key event in the differentiation process [145]. NO inhibits collagen and proteoglycan synthesis. It also activates MMPs, mediating chondrocyte apoptosis and promoting inflammatory response in cartilage tissue. However, beneficial effects on bone metabolism by stimulating osteogenesis-related gene/protein expressions have been reported [36,146-148].

In Table 2, we list the papers that have investigated the ability of LRAP to induce synthesis of bone mineralized extracellular matrix [8,34-36]. Warotayanon and colleagues were the first to test and hypothesize that LRAP could be an alternative pharmacological agent in craniofacial bone tissue and skeletal defects because it induces the expression of bone marker genes in osteogenic-induced ES cells [8,34]. On murine bone marrowderived stromal cells (ST2), LRAP, at a concentration of $10 \mathrm{ng} / \mathrm{mL}$, increased Runt-related transcription factor 2 (Runx2) and osteocalcin without affecting cell proliferation. At this concentration, LRAP in combination with osteogenic medium allowed a significantly higher mineral deposition two weeks after treatment (Figure 3A) [35]. In a recent work of Newcomb and colleagues, ST2 cells osteogenesis was stimulated with LRAP seeded into an amphiphilic peptide-based scaffold. They have reported that LRAP has a dose-dependent activity, showing both an increased calcium phosphate deposition (Figure 3B) and an increased expression of osteogenic markers, such as Runx2, Osx (osterix), Dlx 5 (distal-less homeobox 5), and Col2a1 (collagen type 2 alpha 1), comparable with the control group (C2C12-immortalized mouse myoblast cell line) treated with BMP-2, further underlying the role of LRAP in osteogenesis [36].

The study of Matsuda et al. investigated the effect of chemically synthesized LRAP (csLRAP) on chondrogenic or osteogenic differentiation of the ATDC5 and the MC3T3-E1 cells. Both chondrogenic and osteoblast cells showed a significant suppression in cell number in the presence of csLRAP at $10 \mu \mathrm{g} / \mathrm{mL}$ compared to the control. Furthermore, the intensity of alcian blue staining in chondrogenic cells and alizarin red staining in osteoblast cells were significantly increased in the presence of csLRAP at a dose of $10 \mu \mathrm{g} / \mathrm{mL}$ after four weeks of culture. Chondrogenic or osteogenic differentiation marker genes, including Sox9, Col2a1, Col10a1, Runx2, Alpl (alkaline phosphatase), and Col1a1, were upregulated in the presence of csLRAP after one week of culture. Interestingly, all these effects were suppressed in the presence of LAMP-1 antibody. Together, these results suggest that csLRAP 
could promote osteogenic and chondrogenic differentiation in vitro and that LAMP-1 may be involved in the differentiation and proliferation of these cells [37]. In fact, there is a previous report that describes LRAP as a negative regulator of osteoclastogenesis [26], underlining the role of LRAP in bone regeneration.
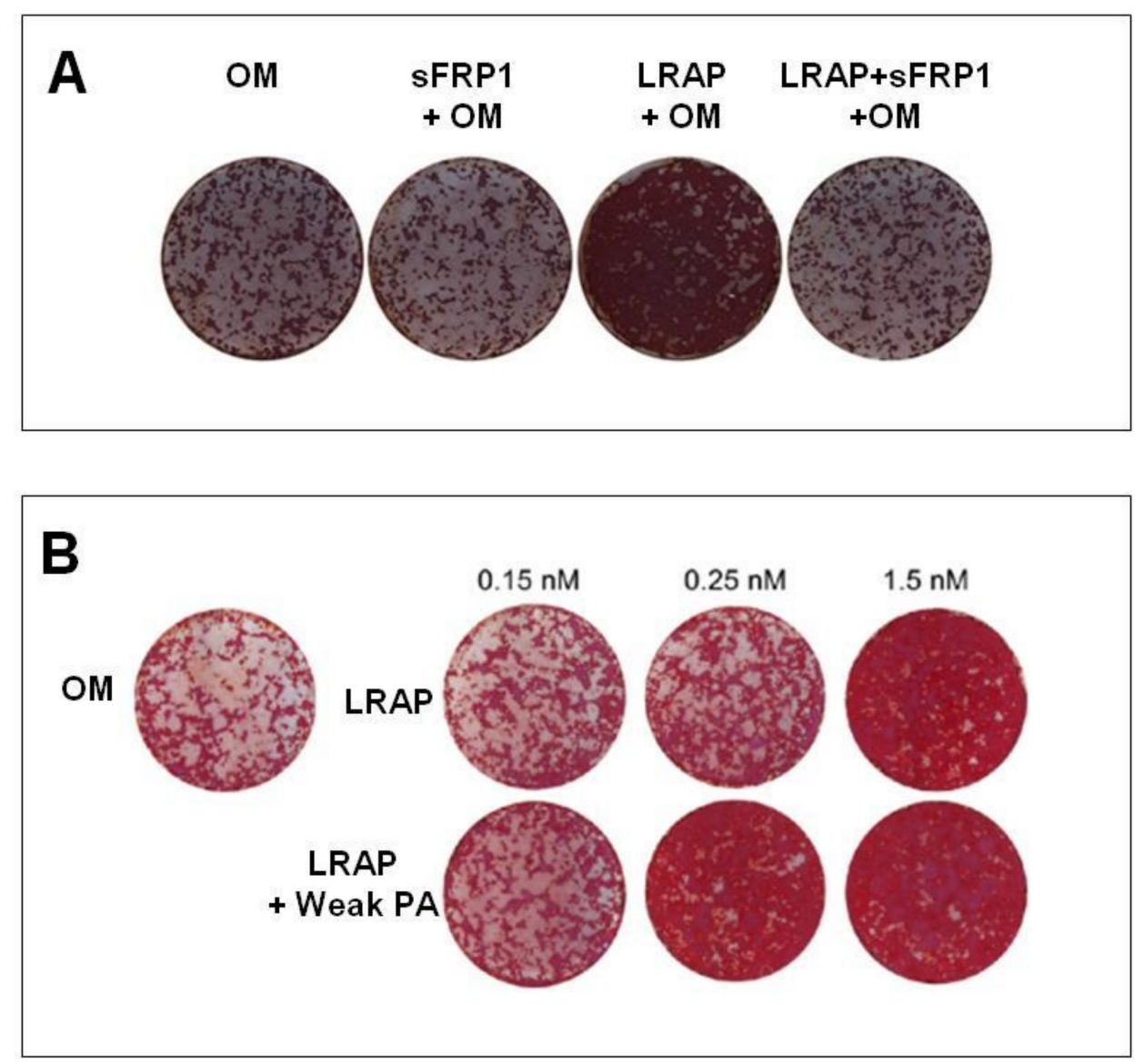

Figure 3. (A) Wnt antagonist sFRP-1 abolishes the effect of LRAP on the stimulation of osteogenesis of ST2 cells. Alizarin red staining for analysis of mineral deposition two weeks after osteo-induction (Reproduced with permission from [35]); (B) Differentiation of ST2 bone marrow stromal cells treated with the LRAP signaling molecule. Two weeks after bone induction, mineral deposition was assayed with alizarin red staining. (Reproduced from [36]. This is an unofficial adaptation of an article that appeared in an ACS publication. ACS has not endorsed the content of this adaptation or the context of its use.)

Of note, LRAP and the full-length AMG showed an opposite effect also on cell proliferation, although in two different cell models. Wen $X$ et al. reported that LRAP has no effect on the proliferation of ST2 cells [35]; on the contrary, human recombinant full-length AMG has been shown to increase the proliferation rate of human bone marrow mesenchymal stem cells [149].

There are no in vivo studies that demonstrate the effectiveness of recombinant LRAP alone in bone regeneration. However, EMD fraction rich in LRAP and ameloblastin, that the authors call "pool 7", was tested and injected in the sub-periosteal calvaria of mice [84]. Authors reported an increased induction of phospho-SMAD, Osterix, and VEGF- $\alpha$. In this in vivo study, the solution also containing LRAP was administered daily for five days, and the stimulus was then regenerated at each administration. Of particular interest is the induction of the transcription factor Osterix, a key regulator in bone formation [150]. LRAP increases the transcriptional level of key genes such as COLL1A1 (collagen, type I a1), and recently it has been demonstrated to directly regulate the angiogenetic factor VEGF- $\alpha$, thus linking bone formation to angiogenesis [151]. Regarding the other higher molecular weight 
components of EMD, Villa O. et al. indicate that they might be related to an angiogenic effect through the stimulation of VEGF release and might modulate wound healing through the expression of IL-6 [152]. These findings indicate that some components of "pool 7" of commercially available EMD can activate BMP signaling within the periosteum, in the newly induced osteoblasts, as previously suggested by Zhao $M$ et al. [153]. Obviously, these results should be considered in relation to the presence of osteoblastin. In fact, other authors describe this protein as a positive modulator of BMP signaling [153].

\subsubsection{LRAP Candidate Receptors}

For a long time, it was unclear how AMG interacts with target cells to increase the expression of the osteogenetic markers that we have previously listed. Although specific receptors for each component of the enamel matrix (including LRAP) remain to be consolidated, some evidence has suggested that cellular uptake of enamel matrix proteins by different cell-types involves receptor-mediated endocytosis.

Before 2016, there are no studies evaluating the interaction between LRAP and cell membrane proteins. All researchers investigated the EMD fractions or the recombinant full-length AMG.

In a pioneering work of Wang $\mathrm{HJ}$ et al., different proteins, such as the eukaryotic translation elongation factor 2 (Eef2), the fasciculation and elongation protein zeta 1 (Fez1), and the small nuclear RNA-specific Sm-like protein splicing factor (Lsm10), were described as possible LRAP binding proteins [27]. It is well established that full-length AMG can bind membrane proteins such as LAMP1 and LAMP-3 (CD63), two proteins associated with endosomal/lysosomal membrane and Annexin A2 (ANXA2), not only on ameloblasts [154] but on different cell lines [90,121,122,142]. If cell surface LAMP-1 was blocked with an antibody, the sorting of exotic vesicles changes increasing the level of intracellular recombinant AMG [124]. An autocrine interaction between LAMP-1 and rM150 (recombinant mouse AMG) was also observed in osteoblastic cells lines [120-122]. In fact, in this case, authors demonstrate that rM150 induced an up-regulation of the LAMP1 receptor. The key relationship between LRAP and LAMP-1 is demonstrated by the fact that several differentiation marker genes in MC3T3-E1 cells were increased by synthetic LRAP and, conversely, were suppressed in the presence of LAMP-1 antibody [142]. The involvement of LAMP-1 as LRAP receptor was further pointed out by Matsuda and coworkers [37].

In addition, LAMP-3 was shown to bind M180 proteins [122]. As reported by Amin et al., some component(s) of the commercial preparation of EMD (Fraction A and Fraction C) bind(s) only PDL cells that express the receptors(s) that mediates direct interaction. These proteins were subsequently internalized and transported to the perinuclear region of the cells with a diffuse cytosolic co-localization with LAMP-1 positive lysosome-like structures [73]. By using immortalized murine cementoblasts (OCCM-30), Martins et al. have demonstrated that LRAP binds LAMP-1, LAMP-3 and, for the first time, Flotillin-1 (Flot-1) [85]. Flot-1 is a ubiquitously expressed and highly conserved protein, which has been suggested to be involved in a variety of cellular processes, such as signal transduction, endocytosis, phagocytosis, cellular trafficking pathways, cell adhesion, and regulation of actin cytoskeleton. Flot- 1 is constitutively associated with lipid rafts, small membrane microdomains enriched in cholesterol and glycosphingolipids $[155,156]$. Lipid rafts function as platforms for various cellular processes, including signal transduction and membrane trafficking [157,158]. An involvement of the ERK/MAPK pathway in cementoblast cells was suggested as an LRAP signaling pathway in 2004 [24]. In particular, it was shown that LRAP-Flot-1 interaction was also involved in signal transduction processes and endocytosis originated from lipid rafts [85].

It is now well accepted that the activation of the canonical Wnt signaling pathway [159] by LRAP induces the osteogenic differentiation of mouse embryonic stem cells (mES), and this activation is more powerful than exogenous Wnt3a in terms of Osx and BSP expression levels and mineral deposition $[8,35]$. Recently, Newcomb et al. have confirmed that the Wnt canonical pathway is activated by LRAP at a concentration of $10 \mathrm{ng} / \mathrm{ml}$. They showed 
that a higher concentration does not exert any increase in the expression of osteogenetic markers because the Wnt signaling cascade is saturated [36].

\subsection{TRAP}

Tyrosine-Rich Amelogenin Peptide (TRAP) is a $5.1 \mathrm{kDa}$ isoform of EMD generated from the full-length AMG through proteolytic cleavage. The amino acid sequence is the following: MPLPPHPGHPGYINFSYEVLTPLKWYQNMIRHPYTSYGYEPMGGW.

The biological role of TRAP in periodontal cells is still matter of debate. In fact, it does not seem to have any effect, not even a suppressive effect, on alveolar bone or the periodontal ligament $[28,84]$. On the other hand, it was reported that chemically synthesized TRAP stimulates angiogenic differentiation of human periodontal ligament stem cells [29,30,160] and angiogenesis in human gingival fibroblasts [161].

The angiogenic property $[162,163]$ and expression of angiogenesis-related proteins in endothelial cells (ECs) $[88,164-166]$ have been widely documented in several in vitro and in vivo studies. However, EMD-derived fraction containing TRAP seems more active than TRAP in stimulating angiogenesis [28]. A plausible explanation of this biological effect was given by Jonke et al. in 2016 [161]. TRAP, isolated from EMD or chemically synthesized, upregulates the expression of adhesion molecules as ICAM-1 and E-selectin, localized on the endothelial cell surface [167,168]; VEGF, that plays a central role in angiogenesis [169]; kinase insert domain receptor (KDR), localized on the endothelial cell surface, with an important role in endothelial cell differentiation; and the FMS-like tyrosine kinase receptors 1 (FLT-1) [170].

Von Willebrand factor (a multimeric glycoprotein known for its contribution to the hemostatic process) upregulation by TRAP was reported for the first time by Amin and colleagues in 2014, and in 2016 by Jonke at al. [29,161]. These authors suggest that TRAP might improve interaction between different cell types and promote VEGF release by resident fibroblasts and VEGF response by endothelial cells during the process of wound healing. Interestingly, TRAP seems to be able also to increase the expression of VEGFR2, an early endothelial marker gene (a tyrosine kinase receptor for the VEGF ligand) on endothelial cells, together with the late genes Tie- 1 and Tie-2, two tyrosine kinase receptors for angiopoietin that are exclusively expressed by endothelial cells [171], and VE-cadherin, an endothelial cell adhesion molecule in human periodontal cells. The angiogenic effect was also demonstrated by using the chicken embryo chorioallantoic membrane assay [29]. The proliferation/viability of endothelial cells was significantly decreased after treatment with TRAP, peptides with either 43 or 45 aminoacidic residues separated and purified from EMD, and synthetic TRAP at a concentration of $100 \mu \mathrm{g} / \mathrm{ml}$ [161].

The low-molecular-weight EMD fraction, containing TRAP, has an osteoblastic effect on PDL fibroblasts [160]. The authors have found increased RUNX2, OPN, OCN, BSP gene expression levels and an increased alkaline phosphatase activity.

In adult primary human articular cartilage cells (HACs), TRAP seems to suppress hypertrophic mineralization and concomitantly promotes chondrogenic differentiation through both early and late chondrogenic gene induction (i.e., SOX9, COL2A1, and ACAN). These results were observed when cells were cultured in chondrogenic conditions supplemented with TRAP $(10 \mu \mathrm{g} / \mathrm{mL})$ but not in control medium (Figure 4) [38]. These results are in agreement with previous reports in which they demonstrated that TRAP suppresses bone-forming activity through Smad6-mediated RUNX2 inhibition [28]. In the same year, Tanimoto and colleagues showed no significant effects on mineralization and expression of osteogenic markers of TRAP on human periodontal ligament cells (HPDLs) [124]. 


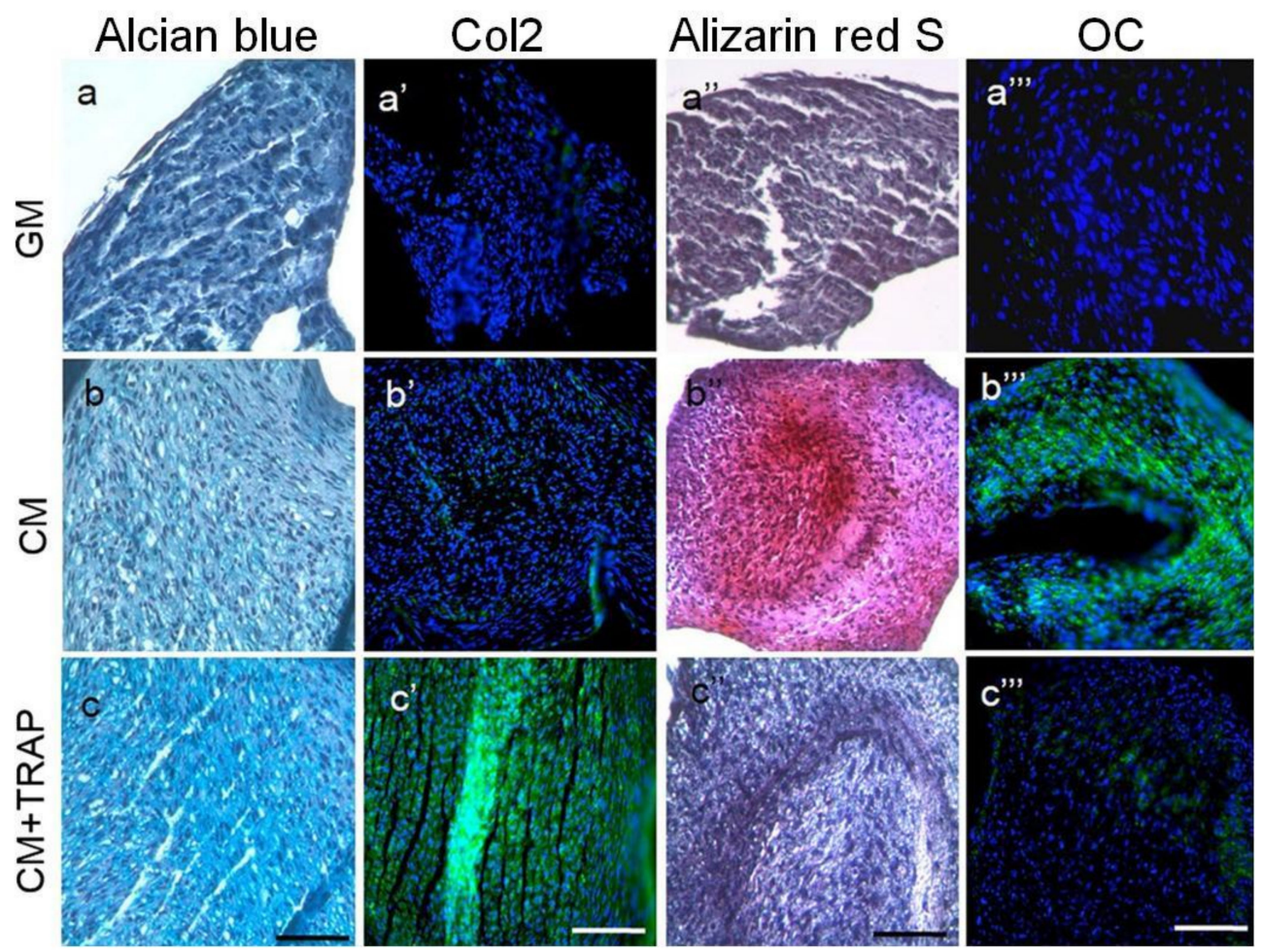

Figure 4. Histology indicates that $10 \mu \mathrm{g} / \mathrm{ml}$ TRAP promotes chondrogenic differentiation and suppresses hypertrophic mineralization. Labels on individual panels refer to culture media type: $\left(\mathbf{a}-\mathbf{a}^{\prime \prime \prime}\right)$ GM; $\left(\mathbf{b}-\mathbf{b}^{\prime \prime \prime}\right)$ CM; (c-c' $\left.{ }^{\prime \prime}\right)$ CM+TRAP. Note the intense bright blue staining of TRAP-treated cell pellets stained with alcian blue (c, indicative of glycosaminoglycans present in the ECM) and the corresponding lack of Alizarin red staining ( $\mathbf{c}^{\prime \prime}$, indicative of minimal calcium deposition). Note also the green fluorescent staining of TRAP-treated cell pellets immuno-stained with Col2 (c') and the corresponding lack of OCN staining $\left(\mathbf{c}^{\prime \prime \prime}\right)$. Alcian blue and alizarin red sections were counter-stained with Harris Haematoxylin (purple nuclei); Col2 and OCN sections were counter-stained with Hoechst dye (blue nuclei). Scale bar $100 \mu \mathrm{m}$. (Reproduced from [38], an open access article distributed under the terms of the Creative Commons CC BY license.)

\subsection{SP (Synthetic Peptide)}

The bioactivity of EMD varies from batch to batch and has been reported to be antigenic and to induce the production of anti-EMD antibodies in the host. To overcome these issues, Kim et al. analyzed the active sites for eosinophilic round bodies (ERBs) binding in EMD-associated proteins using matrix-assisted laser desorption ionization timeof-flight mass spectrometry. They identified a 7 amino acid sequence (WYQNMIR) in AMG that corresponds to a portion of the AMG exon 5. This sequence, named SP, has a molecular mass of $1118 \mathrm{Da}$, and it is less likely than EMD to elicit an immunological response [31].

The use of a synthetic peptide would allow one to avoid the use animal derivatives and would be suitable in terms of safety and reproducibility. Scientific evidence on its potential use in tissue engineering and regenerative medicine appeared in the literature only in 2009 (Table 2).

Periodontal ligament fibroblast treated with SP had an increased expression of genes related to osteogenesis, such as $\mathrm{BMP}$ receptor type $1 \mathrm{~A}, \mathrm{BMP} 4$, osteonectin, $\mathrm{BMP}$ receptor type1 B, osteocalcin, as well as ALP activity, and intracellular calcium deposition with a parallel decreased expression of fibroblast growth factor receptor-like protein 1 [39,42].

These data indicate that SP is effective in periodontal tissue regeneration, suggesting that it may convert human periodontal ligament fibroblasts to bone-forming cells and act as a growth factor. On rat bone marrow cell cultures, SP increases cell proliferation, adhesion, and chemotaxis, reporting significantly higher alkaline phosphatase activity and 
$\mathrm{Ca}^{2+}$ deposition after 7 and 14 days of treatment [41]. Kato and colleagues investigated SP's effect on human periodontal ligament stem cells (PDLSCs), concluding that it can enhance osteoblastic differentiation at early stages of differentiation and can be effective in the initial stage of periodontal tissue regeneration. The authors showed that cell proliferation is significantly increased in the presence of SP in both normal and osteogenic medium. In SP-supplemented osteogenic medium, the expression of osteonectin and osteocalcin mRNA, ALP activity, the number and size of calcified nodules, mineralization, and osteocalcin production were significantly higher than non-supplemented osteogenic medium (Figure 5A) [43].

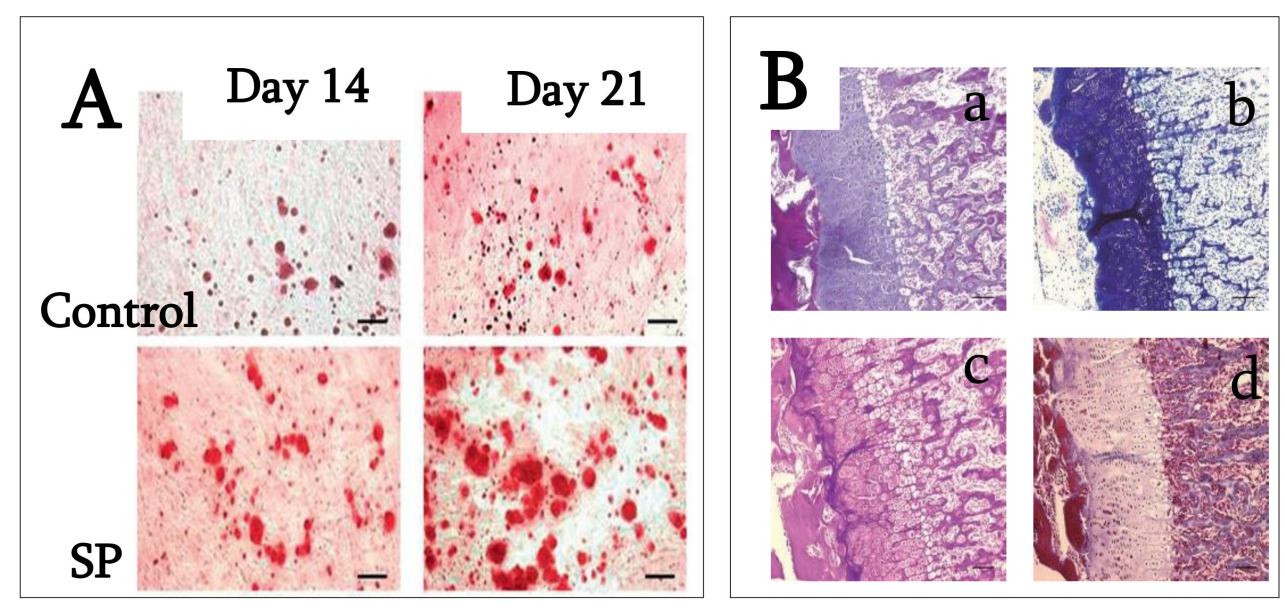

Figure 5. (A) PDLSC cultures were stained with alizarin red S after 14 and 21 days of cultivation in osteogenic medium with and without $100 \mathrm{ng} / \mathrm{mL}$ SP. Calcium deposition on days 14 and 21 was higher in the presence of SP than in its absence. Bar $=100 \mathrm{~mm}$. (Reproduced with permission from [43]). (B) Endochondral ossification and bone formation are observed in the backs of rats 14 days after injection in rats injected with $15 \mathrm{mg} / \mathrm{mL}$ concentration of synthetic peptide (a): hematoxylin and eosin stain). Metachromasia is demonstrated at cartilage tissue with toluidine blue (b). Both cartilage and bone tissue are positive for PAS (c), but negative for Masson trichrome $(\mathbf{d})$. (a-d, original mag. $\times 5$; bar: $0.1 \mathrm{~mm}$; reproduced from [40].)

Thus, SP apparently promotes the mineralization of extracellular matrix on PDLSCs, suggesting that SP promotes PDLSC proliferation, the expression of mineralization markers, and the formation of calcified nodules highlighting the potential of SP in periodontal tissue regeneration. In 2014, Katayama et al. synthesized the same oligopeptide derived from EMD to evaluate its contribution to periodontal tissue regeneration. They investigated the SP effects on cell proliferation and osteoblastic differentiation of human mesenchymal stem cells (MSCs). SP (0 to $1000 \mathrm{ng} / \mathrm{mL}$ ) promoted cell proliferation, osteoblast differentiation, and matrix mineralization, probably through the ERK signaling pathway [44].

These results indicate that SP would be useful for periodontal and bone tissue regeneration because the promotion of MSCs proliferation and differentiation is described as being essential in these processes. Moreover, SP is unlikely to be antigenic and it can be produced synthetically. However, the molecular mechanisms by which SP acts on cells are not yet clearly understood and must be further investigated. Only one paper has investigated SP's ability to induce the extracellular matrix mineralization and bone tissue formation in animal models. SP seems to produce heterotopic ossification in rats when injected under the skin, with endochondral ossification and bone formation within 14 days from the injection (Figure 5B) [40].

\subsection{C11 (Amelogenin C Peptide, AMG-CP)}

A variety of studies suggest that the C-terminal tail of AMG (C11) plays an important role in enamel biomineralization [172]. Zhu et al., using AMG mutated variants (P156T and P164T), demonstrated that the substitution of proline with threonine at position 156 or 164 displayed a significantly lower affinity to HAP, suggesting that these 2 C-terminal 
prolines are important for optimal adsorption of AMG protein to HAP. The prolines appear to be essential conformation determinants that alter the accessibility of AMG C-terminus to apatite, which is related to the growth of apatite crystals and enamel development [173].

It is noteworthy that prolines are found adjacent and upstream to all identified MMP20 cleavage sites in the AMG sequence [174]. Proline is the only cyclic amino acid with a pyrrolidine ring that restricts the conformation range of adjacent residues. The regularly spaced prolines are presumably important in maintaining the extended chain conformation of proteins. The proline residues in the AMG C-terminus are highly conserved across many species, suggesting a functional role for the initial processing of AMG and AMG-mineral interactions.

C11 stimulates the proliferation of human cementoblast-like cell line [175], hAD-MSCs, and hBM-MSCs [32,33], enhancing the phosphorylated ERK1/2 signaling in both cell lines. These effects are inhibited by an anti-LAMP-1 antibody, a condition that further demonstrates the importance of proteins associated with the endosomal/lysosomal membrane in the signal regulation of these peptides [33,175].

Regarding C11's biological role in osteogenic differentiation, the available data indicate that human cementoblast osteogenic differentiation was significantly enhanced by rh128, AMG fragments lacking the N-terminus, and C11, while rh163, AMG fragments lacking the C-terminus, had no significant effect. This indicates the possible utility of C11 in periodontal tissue regeneration (Figure 6) [46]. On the contrary, Awada et al., by using similar C11 concentrations, have found an increased proliferation of mouse MC3T3-E1 cells, but no substantial effects on osteogenic differentiation [45].

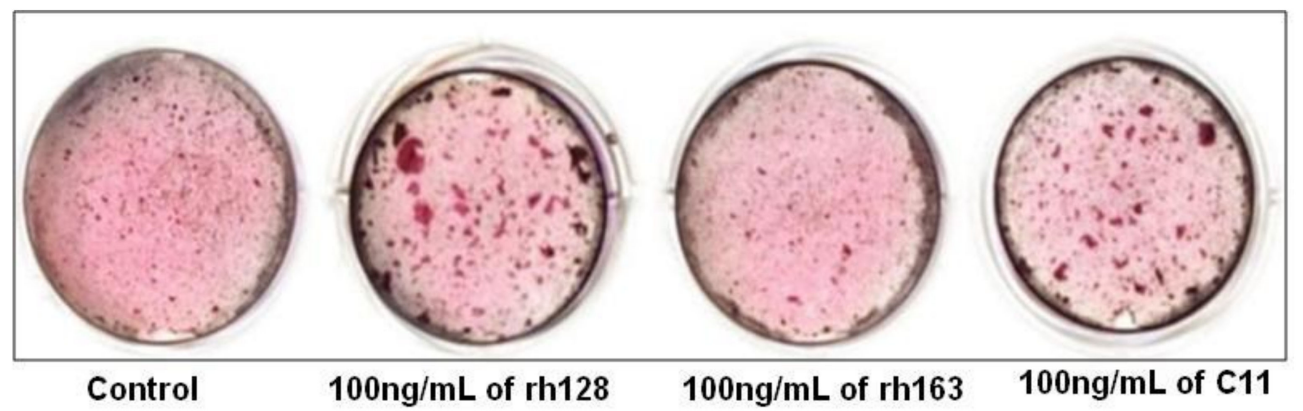

Figure 6. Effect of amelogenin fragment treatment on the mineralization activity of HCEM cells during osteogenic differentiation. Intensity of alizarin red staining in HCEM cells increased following treatment with rh128 or C11 peptide, but there was no obvious difference following treatment with rh163. (Reproduced with permission from [46].)

Overall, these studies suggest the need of future investigations to elucidate $\mathrm{C} 11$ molecular mechanisms, by considering also possible differences due to different experimental protocols.

\section{Conclusions and Future Perspectives}

Since AMG's discovery, over 1500 articles have been published, and proteins and peptides extracted from enamel matrix have been widely used in the last 25 years in regenerative surgery as the support tissue of dental elements, and a total of 132 clinical trials have been published. However, today the effectiveness of these products in promoting bone formation is not clear, and is even discordant in some cases.

In this study, we investigated AMG fragments that have aroused considerable interest in stimulating biomineralization. No clinical studies have verified the use of these peptides in guided bone regeneration procedures. On the basis of in vitro evidence reported here, SP appears to have a significantly higher osteoinductive capacity than LRAP, TRAP, and C11, with a greater tendency to induce osteoblast differentiation and proliferation of non-specialized connective cells and mesenchymal stem cells.

Although LRAP shares many of the biochemical domains with full-length AMG protein, it seems to be more effective in stimulating the formation of mineral nodules through 
the expression of Runx2, Osx, Dlx5, type I collagen, and the production of VEGF1 and IL6. Interestingly, it was also described as a negative regulator of the osteoclastogenesis and adipogenesis. Furthermore, LRAP can play a key role in promoting osteogenesis through the regulation of endosomal-osteoblastic activity and activation of the Wnt canonical signaling pathway. In contrast, TRAP does not appear to have significant effects on bone production but its binding to ICAM-1, E-selectin, KDR, and FMS-like tyrosine kinase receptors 1 stimulates angiogenetic activity and the production of VEGF by fibroblasts.

In different studies, LRAP and TRAP were isolated from animal tissue. This approach introduced a variability in the degrees of purity and titration of peptides used.

AMG C-terminal fragment showed a clear ability to induce proliferation in cells found in periodontal ligament and alveolar bone (i.e., mesenchymal stem cells and osteoblasts), but there are divergent results on its ability to induce bone differentiation. This suggests the need for future investigations on the molecular mechanisms behind the effects of the C-terminal region of the AMG peptide. Yet, there is a potential application of the C-terminal region of the AMG peptide in mesenchymal stem cells, osteoclasts, and other cell-types present in bone formation, which needs to be analyzed more deeply in vitro and in vivo. In fact, several authors have confirmed that the response stimulated by AMG peptides depends strongly on the type, species of origin, and cells treated.

The collected results on SP show that it is as an effective tool in periodontal and bone tissue regeneration. Of note, given the heterogeneity of cell types, culture systems, and molecules used, the information collected in this review should be considered with caution. However, being synthetic peptides, the higher degree of purity and the composition standardization represent an important value-added with respect to AMG from animal sources.

Overall, the use of AMG-derived peptides has influenced researchers, leading to over 50 relevant publications in the last 3 years coming almost exclusively from the dentistry area and related sciences.

We believe that the interest in AMG-derived peptides will grow soon and their potential application in bone regeneration will be further investigated. However, their possibly bright future in bone regeneration will strongly depend on the elucidation of their featured conformations and the understanding of receptor interactions and signal transductions. The use of synthetic or recombinant peptides, with a known composition, will surely increase experiment reproducibility and result consistency. However, the most interesting and reliable knowledge on AMG-derived peptides' aptitude to induce the production of mineralized extracellular matrix will come from in vivo preclinical experiments, which are lacking.

Author Contributions: Conceptualization, A.F. and R.T.; methodology, A.M. and G.P.; software, A.M.; validation, R.T., A.F. and A.M.; formal analysis, A.F. and A.M.; resources, P.B. and G.G.C.; data curation, L.I.D., A.F. and A.M.; writing-original draft preparation, A.F., E.S. and A.M.; writingreview and editing, R.T. and P.B.; supervision, G.G.C. All authors have read and agreed to the published version of the manuscript.

Funding: This research received no external funding.

Institutional Review Board Statement: Not applicable.

Informed Consent Statement: Not applicable.

Conflicts of Interest: The authors declare no conflict of interest.

\section{References}

1. Schliephake, H. Bone growth factors in maxillofacial skeletal reconstruction. Int. J. Oral Maxillofac. Surg. 2002, 31, 469-484. [CrossRef] [PubMed]

2. Margolis, H.C.; Beniash, E.; Fowler, C.E. Role of Macromolecular Assembly of Enamel Matrix Proteins in Enamel Formation. J. Dent. Res. 2006, 85, 775-793. [CrossRef] [PubMed] 
3. Miron, R.J.; Sculean, A.; Cochran, D.L.; Froum, S.; Zucchelli, G.; Nemcovsky, C.; Donos, N.; Lyngstadaas, S.P.; Deschner, J.; Dard, M.; et al. Twenty years of enamel matrix derivative: The past, the present and the future. J. Clin. Periodontol. 2016, 43, 668-683. [CrossRef] [PubMed]

4. Slavkin, H.C.; Bessem, C.; Fincham, A.G.; Bringas, P.; Santos, V.; Snead, M.L.; Zeichner-David, M. Human and mouse cementum proteins immunologically related to enamel proteins. Biochim. Biophys. Acta-Gen. Subj. 1989, 991, 12-18. [CrossRef]

5. Hammarström, L. The role of enamel matrix proteins in the development of cementum and periodontal tissues. Ciba Found. Symp. $1997,205,246-255$.

6. Fong, C.D.; Hammarström, L. Expression of amelin and amelogenin in epithelial root sheath remnants of fully formed rat molars. Oral Surgery Oral Med. Oral Pathol. Oral Radiol. Endodontology 2000, 90, 218-223. [CrossRef]

7. Sonoyama, W.; Seo, B.-M.; Yamaza, T.; Shi, S. Human Hertwig's Epithelial Root Sheath Cells Play Crucial Roles in Cementum Formation. J. Dent. Res. 2007, 86, 594-599. [CrossRef]

8. Warotayanont, R.; Frenkel, B.; Snead, M.L.; Zhou, Y. Leucine-rich amelogenin peptide induces osteogenesis by activation of the Wnt pathway. Biochem. Biophys. Res. Commun. 2009, 387, 558-563. [CrossRef]

9. Haze, A.; Taylor, A.L.; Blumenfeld, A.; Rosenfeld, E.; Leiser, Y.; Dafni, L.; Shay, B.; Gruenbaum-Cohen, Y.; Fermon, E.; Haegewald, S.; et al. Amelogenin expression in long bone and cartilage cells and in bone marrow progenitor cells. Anat. Rec. Adv. Integr. Anat. Evol. Biol. 2007, 290, 455-460. [CrossRef]

10. Deutsch, D.; Haze-Filderman, A.; Blumenfeld, A.; Dafni, L.; Leiser, Y.; Shay, B.; Gruenbaum-Cohen, Y.; Rosenfeld, E.; Fermon, E.; Zimmermann, B.; et al. Amelogenin, a major structural protein in mineralizing enamel, is also expressed in soft tissues: Brain and cells of the hematopoietic system. Eur. J. Oral Sci. 2006, 114, 183-189. [CrossRef]

11. Veis, A.; Tompkins, K.; Alvares, K.; Wei, K.; Wang, L.; Wang, X.S.; Brownell, A.G.; Jengh, S.-M.; Healy, K.E. Specific Amelogenin Gene Splice Products Have Signaling Effects on Cells in Culture and in Implants in Vivo. J. Biol. Chem. 2000, 275, 41263-41272. [CrossRef] [PubMed]

12. Tompkins, K.; Veis, A. Polypeptides translated from alternatively spliced transcripts of the amelogenin gene, devoid of the exon 6a, b, c region, have specific effects on tooth germ development in culture. Connect. Tissue Res. 2002, 43, 224-231. [CrossRef]

13. Veis, A. Amelogenin gene splice products: Potential signaling molecules. Cell. Mol. Life Sci. 2003, 60, 38-55. [CrossRef]

14. Tompkins, K.; Alvares, K.; George, A.; Veis, A. Two related low molecular mass polypeptide isoforms of amelogenin have dis-tinct activities in mouse tooth germ differentiation in vitro. J. Bone Miner. Res. 2005, 20, 341-349. [CrossRef] [PubMed]

15. Urist, M.R. Bone histogenesis and morphogenesis in implants of demineralized enamel and dentin. J. Oral. Surg. 1971, 29, 88-102. [PubMed]

16. Yeomans, D.J.; Urist, M.R. Bone induction by decalcified dentin implanted into oral osseous and muscle tissues. Arch. Oral Biol. 1967, 12, 999-1008. [CrossRef]

17. Nebgen, D.; Inoue, H.; Sabsay, B.; Wei, K.; Ho, C.-S.; Veis, A. Identification of the chondrogenic-inducing activity from bovine dentin (bCIA) as a low-molecular-mass amelogenin polypeptide. J. Dent. Res. 1999, 78, 1484-1494. [CrossRef]

18. Fincham, A.; Moradianoldak, J. Amelogenin Post-translational Modifications: Carboxy-Terminal Processing and the Phosphorylation of Bovine and Porcine "TRAP" and "LRAP" Amelogenins. Biochem. Biophys. Res. Commun. 1993, 197, 248-255. [CrossRef] [PubMed]

19. Nagano, T.; Kakegawa, A.; Yamakoshi, Y.; Tsuchiya, S.; Hu, J.-C.; Gomi, K.; Arai, T.; Bartlett, J.; Simmer, J. Mmp-20 and Klk4 Cleavage Site Preferences for Amelogenin Sequences. J. Dent. Res. 2009, 88, 823-828. [CrossRef]

20. Haruyama, N.; Hatakeyama, J.; Moriyama, K.; Kulkarni, A.B. Amelogenins: Multi-Functional Enamel Matrix Proteins and Their Binding Partners. J. Oral Biosci. 2011, 53, 257-266. [CrossRef]

21. Grandin, H.M.; Gemperli, A.C.; Dard, M. Enamel matrix derivative: A review of cellular effects in vitro and a model of mo-lecular arrangement and functioning. Tissue Eng. Part B. Rev. 2012, 18, 181-202. [CrossRef] [PubMed]

22. Wyganowska-Swiatkowska, M.; Urbaniak, P.; Nohawica, M.; Kotwicka, M.; Jankun, J. Enamel matrix proteins exhibit growth factor activity: A review of evidence at the cellular and molecular levels. Exp. Ther. Med. 2015, 9, 2025-2033. [CrossRef] [PubMed]

23. Giannobile, W.V.; Somerman, M.J. Growth and Amelogenin-Like Factors in Periodontal Wound Healing. A Systematic Re-view. Ann. Periodontol. 2003, 8, 193-204. [CrossRef] [PubMed]

24. Boabaid, F.; Gibson, C.W.; Kuehl, M.A.; Berry, J.E.; Snead, M.L.; Nociti, F.H.; Katchburian, E.; Somerman, M.J. Leucine-Rich Amelogenin Peptide: A Candidate Signaling Molecule During Cementogenesis. J. Periodontol. 2004, 75, 1126-1136. [CrossRef]

25. Le Norcy, E.; Kwak, S.Y.; Wiedemann-Bidlack, F.B.; Beniash, E.; Yamakoshi, Y.; Simmer, J.P.; Margolis, H.C. Leucine-rich amelogenin peptides regulate mineralization in vitro. J. Dent. Res. 2011, 90, 1091-1097. [CrossRef]

26. Hatakeyama, J.; Philp, D.; Haruyama, N.; Shum, L.; Aragon, M.; Yuan, Z.; Gibson, C.; Sreenath, T.; Kleinman, H.; Kulkarni, A.; et al. Amelogenin-mediated Regulation of Osteoclastogenesis, and Periodontal Cell Proliferation and Migration. J. Dent. Res. 2006, 85, 144-149. [CrossRef]

27. Wang, H.-J.; Tannukit, S.; Wen, X.; Shapiro, J.L.; Snead, M.L.; Paine, M.L. Using the yeast two-hybrid assay to discover protein partners for the leucine-rich amelogenin peptide and for tuftelin-interacting protein 11. Eur. J. Oral Sci. 2006, 114, 276-279. [CrossRef]

28. Amin, H.D.; Olsen, I.; Knowles, J.C.; Donos, N. Differential Effect of Amelogenin Peptides on Osteogenic Differentiation In Vitro: Identification of Possible New Drugs for Bone Repair and Regeneration. Tissue Eng. Part A 2012, 18, 1193-1202. [CrossRef] 
29. Amin, H.D.; Olsen, I.; Knowles, J.; Dard, M.; Donos, N. A tyrosine-rich amelogenin peptide promotes neovasculogenesis in vitro and ex vi-vo. Acta Biomater. 2014, 10, 1930-1939. [CrossRef]

30. Amin, H.D.; Olsen, I.; Knowles, J.; Dard, M.; Donos, N. A procedure for identifying stem cell compartments with multi-lineage differentia-tion potential. Analyst 2011, 136, 1440-1449. [CrossRef] [PubMed]

31. Kim, N.H.; Tominaga, K.; Tanaka, A. Analysis of eosinophilic round bodies formed after injection of enamel matrix deriva-tive into the backs of rats. J. Periodontol. 2005, 76, 1934-1941. [CrossRef]

32. Ando, K.; Kunimatsu, R.; Awada, T.; Yoshimi, Y.; Tsuka, Y.; Sumi, K.; Horie, K.; Abe, T.; Nakajima, K.; Tanimoto, K. Effects of Human Full-length Amelogenin and C-terminal Amelogenin Peptide on the Proliferation of Human Mesenchymal Stem Cells Derived from Adipose Tissue. Curr. Pharm. Des. 2018, 24, 2993-3001. [CrossRef] [PubMed]

33. Kunimatsu, R.; Awada, T.; Yoshimi, Y.; Ando, K.; Hirose, N.; Tanne, Y.; Sumi, K.; Tanimoto, K. The C-terminus of the amelogenin peptide influences the proliferation of hu-man bone marrow mesenchymal stem cells. J. Periodontol. 2018, 89, 496-505. [CrossRef] [PubMed]

34. Warotayanont, R.; Zhu, D.; Snead, M.L.; Zhou, Y. Leucine-rich amelogenin peptide induces osteogenesis in mouse embryonic stem cells. Biochem. Biophys. Res. Commun. 2008, 367, 1-6. [CrossRef] [PubMed]

35. Wen, X.; Cawthorn, W.P.; MacDougald, O.A.; Stupp, S.I.; Snead, M.L.; Zhou, Y. The influence of Leucine-rich amelogenin peptide on MSC fate by induc-ing Wnt10b expression. Biomaterials 2011, 32, 6478-6486. [CrossRef]

36. Newcomb, C.J.; Sur, S.; Lee, S.S.; Yu, J.M.; Zhou, Y.; Snead, M.L.; Stupp, S.I. Supramolecular Nanofibers Enhance Growth Factor Signaling by Increasing Lipid Raft Mobility. Nano Lett. 2016, 16, 3042-3050. [CrossRef] [PubMed]

37. Matsuda, Y.; Hatakeyama, Y.; Nakashima, K.; Kamogashira, N.; Hatakeyama, J.; Tamaoki, S.; Sawa, Y.; Ishikawa, H. Effects of a Chemically Synthesized Leucine-Rich Amelogenin Peptide (csLRAP) on Chondrogenic and Osteogenic Cells. J. Hard Tissue Biol. 2017, 26, 51-60. [CrossRef]

38. Amin, H.D.; Ethier, C.R. Differential effects of tyrosine-rich amelogenin peptide on chondrogenic and osteogenic differenti-ation of adult chondrocytes. Cell Tissue Res. 2016, 364, 219-224. [CrossRef]

39. Kawanaka, A.; Tominaga, K.; Tanaka, A. Effect of peptide derived from Emdogain on human periodontal ligament fibro-blast. J. Osaka Dent. Univ. 2009, 43, 111-117.

40. Hida, T.; Tominaga, K.; Tanaka, A. Tissue Reaction to Synthetic Oligopeptide Derived from Enamel Matrix Derivative in Rats. Oral Sci. Int. 2010, 7, 26-33. [CrossRef]

41. Yasui, N.; Taguchi, Y.; Tanaka, A.; Ueda, M.; Umeda, M. Biologic effects of Emdogain Derived Oligopeptides on rat bone marrow cells. J. Oral Tissue Eng. 2012, 9, 126-135.

42. Taguchi, Y.; Yasui, N.; Takahashi, S.; Tominaga, K.; Kato, H.; Komasa, S.; Shida, M.; Hayashi, H.; Tanaka, A.; Umeda, M. Hard Tissue Formation by Human Periodontal Ligament Fibroblast Cells Treated with an Emdogain-Derived Oligopeptide in vitro. J. Hard Tissue Biol. 2012, 21, 375-384. [CrossRef]

43. Kato, H.; Katayama, N.; Taguchi, Y.; Tominaga, K.; Umeda, M.; Tanaka, A. A synthetic oligopeptide derived from enamel matrix derivative promotes the dif-ferentiation of human periodontal ligament stem cells into osteoblast-like cells with increased mineralization. J. Periodontol. 2013, 84, 1476-1483. [CrossRef] [PubMed]

44. Katayama, N.; Kato, H.; Taguchi, Y.; Tanaka, A.; Umeda, M. The Effects of Synthetic Oligopeptide Derived from Enamel Matrix Derivative on Cell Proliferation and Osteoblastic Differentiation of Human Mesenchymal Stem Cells. Int. J. Mol. Sci. 2014, 15, 14026-14043. [CrossRef] [PubMed]

45. Awada, T.; Kunimatsu, R.; Yoshimi, Y.; Hirose, N.; Mitsuyoshi, T.; Sumi, K.; Tanimoto, K. Effects of C-terminal amelogenin pep-tides on the metabolism of osteoblasts. Biochem. Biophys. Res. Commun. 2017, 482, 1154-1159. [CrossRef]

46. Kunimatsu, R.; Yoshimi, Y.; Hirose, N.; Awada, T.; Miyauchi, M.; Takata, T.; Li, W.; Zhu, L.; DenBesten, P.; Tanimoto, K. The C-terminus of amelogenin enhances osteogenic differentiation of human cementoblast lineage cells. J. Periodontal Res. 2016, 52, 218-224. [CrossRef]

47. Eastoe, J.E. The chemical composition of bone and teeth. Adv. Fluorine Res. Dent. Caries Prevent. 1965, 3, 5-17.

48. Takagi, T.; Suzuki, M.; Baba, T.; Minegishi, K.; Sasaki, S. Complete amino acid sequence of amelogenin in developing bovine enamel. Biochem. Biophys. Res. Commun. 1984, 121, 592-597. [CrossRef]

49. Lau, E.C.; Mohandas, T.K.; Shapiro, L.J.; Slavkin, H.C.; Snead, M.L. Human and mouse amelogenin gene loci are on the sex chromosomes. Genomics 1989, 4, 162-168. [CrossRef]

50. Gibson, C.W.; Golub, E.E.; Abrams, W.R.; Shen, G.; Ding, W.; Rosenbloom, J. Bovine amelogenin message heterogeneity: Alternative splicing and Y-chromosomal gene transcription. Biochemistry 1992, 31, 8384-8388. [CrossRef]

51. Lau, E.C.; Simmer, J.P.; Bringas, P.; Hsu, D.D.-J.; Hu, C.-C.; Zeichner-David, M.; Thiemann, F.T.; Snead, M.L.; Slavkin, H.C.; Fincham, A.G. Alternative splicing of the mouse amelogenin primary RNA transcript contributes to amelogenin heterogeneity. Biochem. Biophys. Res. Commun. 1992, 188, 1253-1260. [CrossRef]

52. Bonass, W.A.; Kirkham, J.; Brookes, S.J.; Shore, R.C.; Robinson, C. Isolation and characterisation of an alternatively-spliced rat amelogenin cDNA: LRAP-a highly conserved, functional alternatively-splicedamelogenin? Biochim. Biophys. Acta Gene Struct. Expr. 1994, 1219, 690-692. [CrossRef]

53. Nakahori, Y.; Takenaka, O.; Nakagome, Y. A human X-Y homologous region encodes “amelogenin. " Genomics 1991, 9, 264-269. [CrossRef] 
54. Iwase, M.; Kaneko, S.; Kim, H.L.; Satta, Y.; Takahata, N. Evolutionary History of Sex-Linked Mammalian Amelogenin Genes. Cells Tissues Organs 2007, 186, 49-59. [CrossRef] [PubMed]

55. Fincham, A.; Hu, Y.; Lau, E.; Slavkin, H.; Snead, M. Amelogenin post-secretory processing during biomineralization in the postnatal mouse molar tooth. Arch. Oral Biol. 1991, 36, 305-317. [CrossRef]

56. Bansal, A.K.; Shetty, D.C.; Bindal, R.; Pathak, A. Amelogenin: A novel protein with diverse applications in genetic and molecular profiling. J. Oral Maxillofac. Pathol. 2012, 16, 395-399. [CrossRef]

57. Francès, F.; Portolés, O.; González, J.; Coltell, O.; Verdú, F.; Castello, A.; Corella, D. Amelogenin test: From forensics to quality control in clinical and biochemical genomics. Clin. Chim. Acta 2007, 386, 53-56. [CrossRef]

58. Thangaraj, K.; Reddy, A.G.; Singh, L. Is the amelogenin gene reliable for gender identification in forensic casework and pre-natal diagnosis? Int. J. Legal Med. 2002, 116, 121-123. [CrossRef]

59. Dutta, P.; Bhosale, S.; Singh, R.; Gubrellay, P.; Patil, J.; Sehdev, B.; Bhagat, S.; Bansal, T. Amelogenin Gene-The Pioneer in Gender Determination from Forensic Dental Samples. J. Clin. Diagn. Res. 2017, 11, ZC56-ZC59. [CrossRef] [PubMed]

60. Van den Berge, M.; Sijen, T. A male and female RNA marker to infer sex in forensic analysis. Forensic Sci. Int. Genet. 2017, 26, 70-76. [CrossRef] [PubMed]

61. Fincham, A.; Moradian-Oldak, J.; Simmer, J. The Structural Biology of the Developing Dental Enamel Matrix. J. Struct. Biol. 1999, 126, 270-299. [CrossRef] [PubMed]

62. Toyosawa, S.; O’Huigin, C.; Figueroa, F.; Tichy, H.; Klein, J. Identification and characterization of amelogenin genes in monotremes, reptiles, and amphibians. Proc. Natl. Acad. Sci. USA 1998, 95, 13056-13061. [CrossRef] [PubMed]

63. Brookes, S.; Bonass, W.; Kirkham, J.; Robinson, C. The Human Amelogenin C-terminal Sequence is Completely Homologous to the C-terminal Sequence of Amelogenin in All Species So Far Studied. J. Dent. Res. 1994, 73, 716-717. [CrossRef] [PubMed]

64. Goto, Y.; Kogure, E.; Takagi, T.; Aimoto, S.; Aobo, T. Molecular Conformation of Porcine Amelogenin in Solution: Three Folding Units at the N-terminal, Central, and C-Terminal Regions1. J. Biochem. 1993, 113, 55-60. [CrossRef] [PubMed]

65. Matsushima, N.; Izumi, Y.; Aoba, T. Small-Angle X-Ray Scattering and Computer-Aided Molecular Modeling Studies of 20 kDa Fragment of Porcine Amelogenin: Does Amelogenin Adopt an Elongated Bundle Structure? J. Biochem. 1998, 123, 150-156. [CrossRef]

66. Zhang, X.; Ramirez, B.E.; Liao, X.; Diekwisch, Y.G.H. Amelogenin supramolecular assembly in nanospheres defined by a complex He-lix-Coil-PPII helix 3D-Structure. PLoS ONE 2011, 6, e24952.

67. Bromley, K.M.; Kiss, A.S.; Lokappa, S.B.; Ndao, M.; Evans, J.S.; Moradian-Oldak, J. Dissecting amelogenin protein nanospheres: Characterization of metastable ol-igomers. J. Biol. Chem. 2011, 286, 34643-34653. [CrossRef]

68. Buchko, G.W.; Tarasevich, B.J.; Bekhazi, J.; Snead, M.L.; Shaw, W.J. A solution NMR investigation into the early events of amelogenin nano-sphere self-assembly initiated with sodium chloride or calcium chloride. Biochemistry 2008, 47, 13215-13222. [CrossRef]

69. Moradian-Oldak, J.; Wen, H.B.; Fincham, A.G.; Iijima, M. Amelogenin nanospheres modulate crystal habit of octacalcium phos-phate and hydroxyapatite crystals in in vitro model systems. MRS Online Proc. Libr. 2000, 620, 471.

70. Fang, P.-A.; Margolis, H.C.; Conway, J.F.; Simmer, J.P.; Dickinson, G.H.; Beniash, E. Cryogenic Transmission Electron Microscopy Study of Amelogenin Self-Assembly at Different pH. Cells Tissues Organs 2011, 194, 166-170. [CrossRef] [PubMed]

71. Hammarström, L.; Heijl, L.; Gestrelius, S. Periodontal regeneration in a buccal dehiscence model in monkeys after applica-tion of enamel matrix proteins. J. Clin. Periodontol. 1997, 24, 669-677. [CrossRef] [PubMed]

72. Esposito, M.; Grusovin, M.G.; Coulthard, P.; Worthington, H.V. Enamel matrix derivative (Emdogain) for periodontal tissue regenera-tion in intrabony defects. A Cochrane systematic review. Eur. J. Oral Implantol. 2009, 2, 247-266. [PubMed]

73. Amin, H.; Olsen, I.; Knowles, J.; Dard, M.; Donos, N. Interaction of enamel matrix proteins with human periodontal ligament cells. Clin. Oral Investig. 2016, 20, 339-347. [CrossRef] [PubMed]

74. Johnson, D.L.; Carnes, D.; Steffensen, B.; Cochran, D.L. Cellular Effects of Enamel Matrix Derivative Are Associated With Different Molecular Weight Fractions Following Separation by Size-Exclusion Chromatography. J. Periodontol. 2009, 80, 648-656. [CrossRef]

75. Suzuki, S.; Nagano, T.; Yamakoshi, Y.; Gomi, K.; Arai, T.; Fukae, M.; Katagiri, T.; Oida, S. Enamel matrix derivative gel stimulates signal transduction of BMP and TGF-\{beta\}. J. Dent. Res. 2005, 84, 510-514. [CrossRef]

76. Maycock, J.; Wood, S.R.; Brookes, S.J.; Shore, R.C.; Robinson, C.; Kirkham, J. Characterization of a porcine amelogenin preparation, EMDOGAIN, a biological treatment for periodontal disease. Connect. Tissue Res. 2002, 43, 472-476. [CrossRef]

77. Mumulidu, A.; Hildebrand, B.; Fabi, B.; Hammarström, L.; Cochran, D.L.; Dard, M.; LeMoult, S. Purification and analysis of a 5kDa component of enamel matrix derivative. J. Chromatogr. B 2007, 857, 210-218. [CrossRef]

78. Carinci, F.; Piattelli, A.; Guida, L.; Perrotti, V.; Laino, G.; Oliva, A.; Annunziata, M.; Palmieri, A.; Pezzetti, F. Effects of Emdogain on osteoblast gene expression. Oral Dis. 2006, 12, 329-342. [CrossRef]

79. Gestrelius, S.; Lyngstadaas, S.P.; Hammarström, L. Emdogain-periodontal regeneration based on biomimicry. Clin. Oral Investig. 2000, 4, 120-125. [CrossRef]

80. Zeichner-David, M.; Chen, L.-S.; Hsu, Z.; Reyna, J.; Catón, J.; Bringas, P. Amelogenin and ameloblastin show growth-factor like activity in periodontal ligament cells. Eur. J. Oral Sci. 2006, 114, 244-253. [CrossRef]

81. Hu, C.-C.; Fukae, M.; Uchida, T.; Qian, Q.; Zhang, C.; Ryu, O.; Tanabe, T.; Yamakoshi, Y.; Murakami, C.; Dohi, N.; et al. Sheathlin: Cloning, cDNA/Polypeptide Sequences, and Immunolocalization of Porcine Enamel Sheath Proteins. J. Dent. Res. 1997, 76, 648-657. [CrossRef] [PubMed] 
82. Hu, C.-C.; Fukae, M.; Uchida, T.; Qian, Q.; Zhang, C.; Ryu, O.; Tanabe, T.; Yamakoshi, Y.; Murakami, C.; Dohi, N.; et al. Cloning and Characterization of Porcine Enamelin mRNAs. J. Dent. Res. 1997, 76, 1720-1729. [CrossRef] [PubMed]

83. Fukae, M.; Tanabe, T.; Uchida, T.; Lee, S.-K.; Ryu, O.-H.; Murakami, C.; Wakida, K.; Simmer, J.; Yamada, Y.; Bartlett, J. Enamelysin (matrix metalloproteinase-20): Localization in the developing tooth and effects of $\mathrm{pH}$ and calcium on amelogenin hydrolysis. $J$. Dent. Res. 1998, 77, 1580-1588. [CrossRef] [PubMed]

84. Stout, B.M.; Alent, B.J.; Pedalino, P.; Holbrook, R.; Gluhak-Heinrich, J.; Cui, Y.; Harris, M.A.; Gemperli, A.C.; Cochran, D.L.; Deas, D.E.; et al. Enamel Matrix Derivative: Protein Components and Osteoinductive Properties. J. Periodontol. 2014, 85, e9-e17. [CrossRef] [PubMed]

85. Martins, L.; Leme, A.F.P.; Kantovitz, K.R.; Martins, E.N.L.; Sallum, E.A.; Casati, M.Z.; Nociti, F.H.; Junior, F.H.N. Leucine-Rich Amelogenin Peptide (LRAP) Uptake by Cementoblast Requires Flotillin-1 Mediated Endocytosis. J. Cell. Physiol. 2016, 232, 556-565. [CrossRef]

86. Schwartz, Z.; Carnes, D.L., Jr.; Pulliam, R.; Lohmann, C.H.; Sylvia, V.L.; Liu, Y.; Dean, D.D.; Cochran, D.L.; Boyan, B.D. Porcine fetal enamel matrix derivative stimulates proliferation but not differenti-ation of pre-osteoblastic 2T9 cells, inhibits proliferation and stimulates differentiation of osteoblast-like MG63 cells, and increases proliferation and differentiation of normal human osteoblast NHOst cells. J. Periodontol. 2000, 71, 1287-1296.

87. Van der Pauw, M.T.; Van den Bos, T.; Everts, V.; Beertsen, W. Enamel matrix-derived protein stimulates attachment of periodontal ligament fibroblasts and enhances alkaline phosphatase activity and transforming growth factor beta1 release of perio-dontal ligament and gingival fibroblasts. J. Periodontol. 2000, 71, 31-43. [CrossRef] [PubMed]

88. Schlueter, S.R.; Carnes, D.L.; Cochran, D.L. In Vitro Effects of Enamel Matrix Derivative on Microvascular Cells. J. Periodontol. 2007, 78, 141-151. [CrossRef]

89. Saito, K.; Konishi, I.; Nishiguchi, M.; Hoshino, T.; Fujiwara, T. Amelogenin binds to both heparan sulfate and bone morphogenetic protein 2 and pharmacologically suppresses the effect of noggin. Bone 2008, 43, 371-376. [CrossRef]

90. Reseland, J.E.; Reppe, S.; Larsen, A.M.; Berner, H.S.; Reinholt, F.P.; Gautvik, K.M.; Slaby, I.; Lyngstadaas, S.P. The effect of enamel matrix derivative on gene expression in osteoblasts. Eur. J. Oral Sci. 2006, 114, 205-211. [CrossRef]

91. He, J.; Jiang, J.; Safavi, K.E.; Spångberg, L.S.; Zhu, Q. Emdogain promotes osteoblast proliferation and differentiation and stimulates osteopro-tegerin expression. Oral Surg. Oral Med. Oral Pathol. Oral Radiol. Endodontology 2004, 97, 239-245. [CrossRef]

92. He, J.; King, Y.; Jiang, J.; Safavi, K.E.; Spångberg, L.S.; Zhu, Q. Enamel matrix derivative inhibits TNF- $\alpha$-induced apoptosis in osteoblastic MC3T3-E1 cells. Oral Surg. Oral Med. Oral Pathol. Oral Radiol. Endodontol. 2005, 99, 761-767. [CrossRef]

93. Lee, A.Z.; Jiang, J.; He, J.; Safavi, K.E.; Spångberg, L.S.; Zhu, Q. Stimulation of cytokines in osteoblasts cultured on enamel matrix derivative. Oral Surg. Oral Med. Oral Pathol. Oral Radiol. Endodontol. 2008, 106, 133-138. [CrossRef]

94. Miron, R.J.; Oates, C.J.; Molenberg, A.; Dard, M.; Hamilton, D.W. The effect of enamel matrix proteins on the spreading, proliferation and differen-tiation of osteoblasts cultured on titanium surfaces. Biomaterials 2010, 31, 449-460. [CrossRef] [PubMed]

95. Narukawa, M.; Suzuki, N.; Takayama, T.; Shoji, T.; Otsuka, K.; Ito, K. Enamel matrix derivative stimulates chondrogenic differentiation of ATDC5 cells. J. Periodontal Res. 2006, 42, 131-137. [CrossRef]

96. Narukawa, M.; Suzuki, N.; Takayama, T.; Shoji, T.; Otsuka, K.; Ito, K. Enamel matrix derivative stimulates osteogenesis- and chondrogene-sis-related transcription factors in C3H10T1/2 cells. Acta Biochim. Biophys. Sin. 2007, 39, 1-7. [CrossRef]

97. Takayama, T.; Suzuki, N.; Narukawa, M.; Tokunaga, T.; Otsuka, K.; Ito, K. Enamel Matrix Derivative Stimulates Core Binding Factor $\alpha 1 /$ Runt-Related Transcription Factor-2 Expression via Activation of Smad1 in C2C12 Cells. J. Periodontol. 2005, 76, 244-249. [CrossRef] [PubMed]

98. Yoneda, S.; Itoh, D.; Kuroda, S.; Kondo, H.; Umezawa, A.; Ohya, K.; Ohyama, T.; Kasugai, S. The effects of enamel matrix derivative (EMD) on osteoblastic cells in culture and bone regeneration in a rat skull defect. J. Periodontal Res. 2003, 38, 333-342. [CrossRef]

99. Weißhaupt, P.; Bernimoulin, J.-P.; Trackman, P.; Hägewald, S. Stimulation of osteoblasts with Emdogain increases the expression of specific mineralization markers. Oral Surg. Oral Med. Oral Pathol. Oral Radiol. Endodontol. 2008, 106, 304-308. [CrossRef] [PubMed]

100. Rincon, J.C.; Xiao, Y.; Young, W.G.; Bartold, P.M. Production of osteopontin by cultured porcine epithelial cell rests of Malassez. J. Periodontal Res. 2005, 40, 417-426. [CrossRef] [PubMed]

101. Miron, R.J.; Fujioka-Kobayashi, M.; Zhang, Y.; Sculean, A.; Pippenger, B.; Shirakata, Y.; Kandalam, U.; Hernandez, M. Osteogain ${ }^{\circ}$ loaded onto an absorbable collagen sponge induces attachment and osteoblast differentiation of ST2 cells in vitro. Clin Oral Investig. 2017, 21, 2265-2272. [CrossRef]

102. Itoh, N.; Kasai, H.; Ariyoshi, W.; Harada, E.; Yokota, M.; Nishihara, T. Mechanisms involved in the enhancement of osteoclast formation by enamel matrix derivative. J. Periodontal Res. 2006, 41, 273-279. [CrossRef] [PubMed]

103. Otsuka, T.; Kasai, H.; Yamaguchi, K.; Nishihara, T. Enamel matrix derivative promotes osteoclast cell formation by RANKL production in mouse marrow cultures. J. Dent. 2005, 33, 749-755. [CrossRef] [PubMed]

104. Donos, N.; Bosshardt, D.; Lang, N.P.; Graziani, F.; Tonetti, M.; Karring, T.; Kostopoulos, L. Bone formation by enamel matrix proteins and xenografts: An experimental study in the rat ramus. Clin. Oral Implant. Res. 2004, 16, 140-146. [CrossRef] [PubMed]

105. Intini, G.; Andreana, S.; Buhite, R.J.; Bobek, L.A. A Comparative Analysis of Bone Formation Induced by Human Demineralized Freeze-Dried Bone and Enamel Matrix Derivative in Rat Calvaria Critical-Size Bone Defects. J. Periodontol. 2008, 79, 1217-1224. [CrossRef] [PubMed] 
106. Potijanyakul, P.; Sattayasansakul, W.; Pongpanich, S.; Leepong, N.; Kintarak, S. Effects of Enamel Matrix Derivative on Bioactive Glass in Rat Calvarium Defects. J. Oral Implant. 2010, 36, 195-204. [CrossRef]

107. Shahriari, S.; Houshmand, B.; Razavian, H.; Khazaei, S.; Abbas, F.M. Effect of the combination of enamel matrix derivatives and deproteinized bovine bone materials on bone formation in rabbits' calvarial defects. Dent. Res. J. 2012, 9, $422-426$.

108. Sawae, Y.; Sahara, T.; Kawana, F.; Sasaki, T. Effects of enamel matrix derivative on mineralized tissue formation during bone wound healing in rat parietal bone defects. Qjm: Int. J. Med. 2002, 51, 413-423. [CrossRef]

109. Kawana, F.; Sawae, Y.; Sahara, T.; Tanaka, S.; Debari, K.; Shimizu, M.; Sasaki, T. Porcine enamel matrix derivative enhances trabecular bone regeneration during wound healing of injured rat femur. Anat. Rec. Adv. Integr. Anat. Evol. Biol. 2001, 264, 438-446. [CrossRef]

110. Heijl, L.; Heden, G.; Svärdström, G.; Ostgren, A. Enamel matrix derivative (EMDOGAIN) in the treatment of intrabony periodontal defects. J. Clin. Periodontol. 1997, 24, 705-714. [CrossRef]

111. Cornelini, R.; Scarano, A.; Piattelli, M.; Andreana, S.; Covani, U.; Quaranta, A.; Piattelli, A. Effect of Enamel Matrix Derivative (Emdogain) on Bone Defects in Rabbit Tibias. J. Oral Implant. 2004, 30, 69-73. [CrossRef]

112. Wang, H.L.; Boyapati, L. "pASS" principles for predictable bone regeneration. Implant Dent. 2006, 15, 8-17. [CrossRef] [PubMed]

113. Miron, R.J.; Wei, L.; Bosshardt, D.D.; Buser, D.; Sculean, A.; Zhang, Y. Effects of enamel matrix proteins in combination with a bovine-derived natural bone mineral for the repair of bone defects. Clin. Oral Investig. 2013, 18, 471-478. [CrossRef] [PubMed]

114. Galli, C.; Macaluso, G.M.; Guizzardi, S.; Vescovini, R.; Passeri, M.; Passeri, G. Osteoprotegerin and receptor activator of nuclear factor-kappa B ligand mod-ulation by enamel matrix derivative in human alveolar osteoblasts. J. Periodontol. 2006, 77, 1223-1228. [CrossRef] [PubMed]

115. Iwata, T.; Morotome, Y.; Tanabe, T.; Fukae, M.; Ishikawa, I.; Oida, S. Noggin blocks osteoinductive activity of porcine enamel extracts. J. Dent. Res. 2002, 81, 387-391. [CrossRef]

116. Hoang, A.; Klebe, R.; Steffensen, B.; Ryu, O.; Simmer, J.; Cochran, D. Amelogenin is a cell adhesion protein. J. Dent. Res. 2002, 81, 497-500. [CrossRef]

117. Du, C.; Schneider, G.; Zaharias, R.; Abbott, C.; Seabold, D.; Stanford, C.; Moradian-Oldak, J. Apatite/Amelogenin Coating on Titanium Promotes Osteogenic Gene Expression. J. Dent. Res. 2005, 84, 1070-1074. [CrossRef]

118. Svensson, J.; Andersson, C.; Reseland, J.E.; Lyngstadaas, P.; Bülow, L. Histidine tag fusion increases expression levels of active recombinant ame-logenin in Escherichia coli. Protein Expr. Purif. 2006, 48, 134-141. [CrossRef]

119. Terada, C.; Komasa, S.; Kusumoto, T.; Kawazoe, T.; Okazaki, J. Effect of Amelogenin Coating of a Nano-Modified Titanium Surface on Bioactivity. Int. J. Mol. Sci. 2018, 19, 1274. [CrossRef]

120. Fukuda, T.; Sanui, T.; Toyoda, K.; Tanaka, U.; Taketomi, T.; Uchiumi, T.; Nishimura, F. Identification of Novel Amelogenin-Binding Proteins by Proteomics Analysis. PLoS ONE 2013, 8, e78129. [CrossRef]

121. Zhang, H.; Tompkins, K.; Garrigues, J.; Snead, M.L.; Gibson, C.W.; Somerman, M.J. Full length amelogenin binds to cell surface LAMP-1 on tooth root/periodontium associated cells. Arch. Oral Biol. 2010, 55, 417-425. [CrossRef] [PubMed]

122. Toyoda, K.; Fukuda, T.; Sanui, T.; Tanaka, U.; Yamamichi, K.; Atomura, R.; Maeda, H.; Tomokiyo, A.; Taketomi, T.; Uchiumi, T.; et al. Grp78 Is Critical for Amelogenin-Induced Cell Migration in a Multipotent Clonal Human Periodontal Ligament Cell Line. J. Cell. Physiol. 2016, 231, 414-427. [CrossRef]

123. Shapiro, J.L.; Wen, X.; Okamoto, C.T.; Wang, H.J.; Lyngstadaas, S.P.; Goldberg, M.; Snead, M.L.; Paine, M.L. Cellular uptake of amelogenin, and its localization to CD63, and Lamp1-positive vesicles. Cell. Mol. Life Sci. 2006, 64, 244-256. [CrossRef]

124. Tanimoto, K.; Kunimatsu, R.; Tanne, Y.; Huang, Y.-C.; Michida, M.; Yoshimi, Y.; Miyauchi, M.; Takata, T.; Tanne, K. Differential Effects of Amelogenin on Mineralization of Cementoblasts and Periodontal Ligament Cells. J. Periodontol. 2012, 83, 672-679. [CrossRef] [PubMed]

125. Viswanathan, H.L.; Berry, J.E.; Foster, B.L.; Gibson, C.W.; Li, Y.; Kulkarni, A.B.; Snead, M.L.; Somerman, M.J. Amelogenin: A Potential Regulator of Cementum-Associated Genes. J. Periodontol. 2003, 74, 1423-1431. [CrossRef] [PubMed]

126. Swanson, E.C.; Fong, H.K.; Foster, B.L.; Paine, M.L.; Gibson, C.W.; Snead, M.L.; Somerman, M.J. Amelogenins regulate expression of genes associated with cementoblasts in vitro. Eur. J. Oral Sci. 2006, 114, 239-243. [CrossRef]

127. Yuan, Z.; Collier, P.; Rosenbloom, J.; Gibson, C. Analysis of amelogenin mRNA during bovine tooth development. Arch. Oral Biol. 1996, 41, 205-213. [CrossRef]

128. Fincham, A.G.; Belcourt, A.B.; Termine, J.D.; Butler, W.T.; Cothran, W.C. Dental enamel matrix: Sequences of two amelogenin polypeptides. Biosci. Rep. 1981, 1, 771-778. [CrossRef]

129. Masica, D.L.; Gray, J.J.; Shaw, W.J. Partial High-Resolution Structure of Phosphorylated and Non-phosphorylated Leucine-Rich Amelogenin Protein Adsorbed to Hydroxyapatite. J. Phys. Chem. C 2011, 115, 13775-13785. [CrossRef]

130. Lu, J.X.; Xu, Y.S.; Buchko, G.W.; Shaw, W.J. Mineral association changes the secondary structure and dynamics of murine amelog-enin. J. Dent. Res. 2013, 92, 1000-1004. [CrossRef] [PubMed]

131. Tarasevich, B.J.; Perez-Salas, U.; Masica, D.L.; Philo, J.; Kienzle, P.; Krueger, S.; Majkrzak, C.F.; Gray, J.L.; Shaw, W.J. Neutron reflectometry studies of the adsorbed structure of the amelogen-in, LRAP. J. Phys. Chem. B 2013, 117, 3098-3109. [CrossRef]

132. Yamazaki, H.; Beniash, E.; Yamakoshi, Y.; Simmer, J.P.; Margolis, H.C. Protein Phosphorylation and Mineral Binding Affect the Secondary Structure of the Leucine-Rich Amelogenin Peptide. Front. Physiol. 2017, 8. [CrossRef]

133. Ma, C.-W.; Zhang, J.; Dong, X.-Q.; Lu, J.-X. Amyloid structure of high-order assembly of Leucine-rich amelogenin revealed by solid-state NMR. J. Struct. Biol. 2019, 206, 29-35. [CrossRef] [PubMed] 
134. Le, T.Q.; Zhang, Y.; Li, W.; Denbesten, P.K. The effect of LRAP on enamel organ epithelial celldifferentiation. J. Dent Res. 2007, 86, 1095-1099. [CrossRef] [PubMed]

135. Xia, Y.; Ren, A.; Pugach, M.K. Truncated amelogenin and LRAP transgenes improve Amelx null mouse enamel. Matrix Biol. 2016, 52-54, 198-206. [CrossRef] [PubMed]

136. Habelitz, S.; DenBesten, P.K.; Marshall, S.J.; Marshall, G.W.; Li, W. Self-assembly and effect on crystal growth of the leucine-rich amelogenin peptide. Eur. J. Oral Sci. 2006, 114, 315-319. [CrossRef]

137. Tarasevich, B.J.; Lea, S.; Shaw, W.J. The leucine rich amelogenin protein (LRAP) adsorbs as monomers or dimers onto sur-faces. J. Struct. Biol. 2010, 169, 266-276. [CrossRef]

138. Shaw, W.J.; Campbell, A.A.; Paine, M.L.; Snead, M.L. The COOH terminus of the amelogenin, LRAP, is oriented next to the hydrax-yapatite surface. J. Biol. Chem. 2004, 279, 40263-40266. [CrossRef]

139. Shaw, W.J.; Ferris, K.; Tarasevich, B.; Larson, J.L. The Structure and Orientation of the C-Terminus of LRAP. Biophys. J. 2008, 94, 3247-3257. [CrossRef]

140. Le, T.Q.; Gochin, M.; Featherstone, J.D.B.; Li, W.; DenBesten, P.K. Comparative calcium binding of leucine-rich amelogenin pep-tide and full-length amelogenin. Eur. J. Oral Sci. 2006, 114, 320-326. [CrossRef]

141. Sculean, A.; Nikolidakis, D.; Schwarz, F. Regeneration of periodontal tissues: Combinations of barrier membranes and grafting materials-biological foundation and preclinical evidence: A systematic review. J. Clin. Periodontol. 2008, 35, 106-116. [CrossRef] [PubMed]

142. Iacob, S.; Veis, A. Identification of the functional activity of the [A-4] amelogenin gene splice product in newborn mouse ameloblasts. Bone 2008, 42, 1072-1079. [CrossRef] [PubMed]

143. Villalobo, A. Nitric oxide and cell proliferation. FEBS J. 2006, 273, 2329-2344. [CrossRef]

144. Teixeira, C.C.; Ischiropoulos, H.; Leboy, P.S.; Adams, S.L.; Shapiro, I.M. Nitric oxide-nitric oxide synthase regulates key maturational events during chondrocyte terminal differentiation. Bone 2005, 37, 37-45. [CrossRef]

145. Tiribuzi, R.; Crispoltoni, L.; Tartacca, F.; Orlacchio, A.; Martino, S.; Palmerini, C.A.; Orlacchio, A. Nitric oxide depletion alters hematopoietic stem cell commitment toward im-munogenic dendritic cells. Biochim. Biophys. Acta-Gen. Subj. 2013, 1830, 2830-2838. [CrossRef] [PubMed]

146. Speziali, A.; Delcogliano, M.; Tei, M.M.; Placella, G.; Chillemi, M.; Tiribuzi, R.; Cerulli, G. Chondropenia: Current concept review. Musculoskelet. Surg. 2015, 99, 189-200. [CrossRef] [PubMed]

147. Klein-Nulend, J.; van Oers, R.F.M.; Bakker, A.D.; Bacabac, R.G. Nitric oxide signaling in mechanical adaptation of bone. Osteoporos. Int. 2013, 25, 1427-1437. [CrossRef]

148. Zhang, W.; Liu, N.; Shi, H.; Liu, J.; Shi, L.; Zhang, B.; Wang, H.; Ji, J.; Chu, P.K. Upregulation of BMSCs Osteogenesis by Positively-Charged Tertiary Amines on Polymeric Implants via Charge/iNOS Signaling Pathway. Sci. Rep. 2015, 5, 9369. [CrossRef]

149. Huang, Y.C.; Tanimoto, K.; Tanne, Y.; Kamiya, T.; Kunimatsu, R.; Michida, M.; Yoshioka, M.; Yoshimi, Y.; Kato, Y.; Tanne, K. Effects of human full-length amelogenin on the proliferation of human mesen-chymal stem cells derived from bone marrow. Cell Tissue Res. 2010, 342, 205-212. [CrossRef]

150. Zhang, C. Molecular mechanisms of osteoblast-specific transcription factor Osterix effect on bone formation. Beijing Da Xue Xue Bao. Yi Xue Ban J. Peking Univ. Heal. Sci. 2012, 44, 659-665.

151. Tang, W.; Yang, F.; Li, Y.; de Crombrugghe, B.; Jiao, H.; Xiao, G.; Zhang, C. Transcriptional regulation of Vascular Endothelial Growth Factor (VEGF) by osteo-blast-specific transcription factor Osterix (Osx) in osteoblasts. J. Biol. Chem. 2012, 287, 1671-1678. [CrossRef]

152. Villa, O.; Wohlfahrt, J.C.; Mdla, I.; Petzold, C.; Reseland, J.E.; Snead, M.L.; Lyngstadaas, S.P. Proline-Rich Peptide Mimics Effects of Enamel Matrix Derivative on Rat Oral Muco-sa Incisional Wound Healing. J. Periodontol. 2015, 86, 1386-1395. [CrossRef]

153. Zhao, M.; Harris, S.E.; Horn, D.; Geng, Z.; Nishimura, R.; Mundy, G.R.; Chen, D. Bone morphogenetic protein receptor signaling is necessary for normal murine post-natal bone formation. J. Cell Biol. 2002, 157, 1049-1060. [CrossRef] [PubMed]

154. Bartlett, J.D.; Ganss, B.; Goldberg, M.; Moradian-Oldak, J.; Paine, M.L.; Snead, M.L.; Wen, X.; White, S.N.; Zhou, Y.L. ProteinProtein Interactions of the Developing Enamel Matrix. Current Topics Dev. Biol. 2006, 74, 57-115. [CrossRef]

155. Simons, K.; Ikonen, E. Functional rafts in cell membranes. Nature 1997, 387, 569-572. [CrossRef] [PubMed]

156. Simons, K.; Sampaio, J. Membrane Organization and Lipid Rafts. Cold Spring Harb. Perspect. Biol. 2011, 3, a004697. [CrossRef]

157. Banning, A.; Tomasovic, A.; Tikkanen, R. Functional aspects of membrane association of reggie/flotillin proteins. Curr. Protein Pept. Sci. 2011, 12, 725-735. [CrossRef]

158. Zhao, F.; Zhang, J.; Liu, Y.-S.; Li, L.; He, Y.-L. Research advances on flotillins. Virol. J. 2011, 8, 479. [CrossRef]

159. Liu, F.; Kohlmeier, S.; Wang, C.-Y. Wnt signaling and skeletal development. Cell. Signal. 2008, 20, 999-1009. [CrossRef]

160. Amin, H.D.; Olsen, I.; Knowles, J.C.; Dard, M.; Donos, N. Effects of enamel matrix proteins on multi-lineage differentiation of periodontal ligament cells in vitro. Acta Biomater. 2013, 9, 4796-4805. [CrossRef]

161. Jonke, E.; Gemperli, A.C.; Zhang, T.; Özdemir, B.; Dard, M.; Rausch-Fan, X.; Andrukhov, O. Effect of tyrosine-rich amelogenin peptide on behavior and differentiation of en-dothelial cells. Clin. Oral Investig. 2016, 20, 2275-2284. [CrossRef] [PubMed]

162. Aspriello, S.D.; Zizzi, A.; Spazzafumo, L.; Rubini, C.; Lorenzi, T.; Marzioni, D.; Bullon, P.; Piemontese, M. Effects of Enamel Matrix Derivative on Vascular Endothelial Growth Factor Expression and Microvessel Density in Gingival Tissues of Periodontal Pocket: A Comparative Study. J. Periodontol. 2011, 82, 606-612. [CrossRef] [PubMed] 
163. Thoma, D.S.; Villar, C.C.; Carnes, D.L.; Dard, M.; Chun, Y.-H.P.; Cochran, D.L. Angiogenic activity of an enamel matrix derivative (EMD) and EMD-derived proteins: An experimental study in mice. J. Clin. Periodontol. 2010, 38, 253-260. [CrossRef]

164. Kasaj, A.; Meister, J.; Lehmann, K.; Stratul, S.-I.; Schlee, M.; Stein, J.M.; Willershausen, B.; Schmidt, M. The influence of enamel matrix derivative on the angiogenic activity of primary endothelial cells. J. Periodontal Res. 2011, 47, 479-487. [CrossRef] [PubMed]

165. Bertl, K.; An, N.; Bruckmann, C.; Dard, M.; Andrukhov, O.; Matejka, M.; Rausch-Fan, X. Effects of Enamel Matrix Derivative on Proliferation/Viability, Migration, and Ex-pression of Angiogenic Factor and Adhesion Molecules in Endothelial Cells In Vitro. J. Periodontol. 2009, 80, 1622-1630. [CrossRef]

166. Yuan, K.; Chen, C.-L.; Lin, M.T. Enamel matrix derivative exhibits angiogenic effect in vitro and in a murine model. J. Clin. Periodontol. 2003, 30, 732-738. [CrossRef] [PubMed]

167. Martin, P. Wound Healing-Aiming for Perfect Skin Regeneration. Science 1997, 276, 75-81. [CrossRef] [PubMed]

168. Albelda, S.M.; Smith, C.W.; Ward, P.A. Adhesion molecules and inflammatory injury. FASEB J. 1994, 8, 504-512. [CrossRef]

169. Bao, P.; Kodra, A.; Tomic-Canic, M.; Golinko, M.S.; Ehrlich, H.P.; Brem, H. The Role of Vascular Endothelial Growth Factor in Wound Healing. J. Surg. Res. 2009, 153, 347-358. [CrossRef]

170. Peters, K.G.; De Vries, C.; Williams, L.T. Vascular endothelial growth factor receptor expression during embryogenesis and tissue repair suggests a role in endothelial differentiation and blood vessel growth. Proc. Natl. Acad. Sci. USA 1993, 90, 8915-8919. [CrossRef]

171. Jones, N.; Iljin, K.; Dumont, D.J.; Alitalo, K. Tie receptors: New modulators of angiogenic and lymphangiogenic responses. Nat. Rev. Mol. Cell Biol. 2001, 2, 257-267. [CrossRef]

172. Moradian-Oldak, J.; Bouropoulos, N.; Wang, L.; Gharakhanian, N. Analysis of self-assembly and apatite binding properties of amelogenin proteins lacking the hydrophilic C-terminal. Matrix Biol. 2002, 21, 197-205. [CrossRef]

173. Zhu, L.; Tanimoto, K.; Le, T.; DenBesten, P.K.; Li, W. Functional Roles of Prolines at Amelogenin C Terminal during Tooth Enamel Formation. Cells Tissues Organs 2008, 189, 203-206. [CrossRef] [PubMed]

174. Ryu, O.; Fincham, A.; Hu, C.-C.; Zhang, C.; Qian, Q.; Bartlett, J.; Simmer, J. Characterization of recombinant pig enamelysin activity and cleavage of recombinant pig and mouse amelogenins. J. Dent. Res. 1999, 78, 743-750. [CrossRef]

175. Yoshimi, Y.; Kunimatsu, R.; Hirose, N.; Awada, T.; Miyauchi, M.; Takata, T.; Li, W.; Zhu, L.; Denbesten, P.; Tanne, K.; et al. Effects of C-Terminal Amelogenin Peptide on Proliferation of Human Cemento-blast Lineage Cells. J. Periodontol. 2016, 87, 820-827. [CrossRef] [PubMed] 